NBER WORKING PAPER SERIES

\title{
HEALTH CAPACITY TO WORK AT OLDER AGES: EVIDENCE FROM THE U.S.
}

\author{
Courtney Coile \\ Kevin S. Milligan \\ David A. Wise \\ Working Paper 21940 \\ http://www.nber.org/papers/w21940
NATIONAL BUREAU OF ECONOMIC RESEARCH
1050 Massachusetts Avenue
Cambridge, MA 02138
January 2016

This paper is part of the National Bureau of Economic Research's International Social Security (ISS) Project, which is supported by the National Institute on Aging (grant P01 AG012810). The authors are indebted to Maurice Dalton for expert research assistance. We also thank the members of the other country teams in the ISS project for comments that helped to shape this paper, as well as seminar participants at Wellesley College and the Center for Retirement Research at Boston College. The views expressed herein are those of the authors and do not necessarily reflect the views of the National Bureau of Economic Research.

At least one co-author has disclosed a financial relationship of potential relevance for this research. Further information is available online at http://www.nber.org/papers/w21940.ack

NBER working papers are circulated for discussion and comment purposes. They have not been peerreviewed or been subject to the review by the NBER Board of Directors that accompanies official NBER publications.

(C) 2016 by Courtney Coile, Kevin S. Milligan, and David A. Wise. All rights reserved. Short sections of text, not to exceed two paragraphs, may be quoted without explicit permission provided that full credit, including $\odot$ notice, is given to the source. 
Health Capacity to Work at Older Ages: Evidence from the U.S.

Courtney Coile, Kevin S. Milligan, and David A. Wise

NBER Working Paper No. 21940

January 2016

JEL No. I19,J14,J26

\begin{abstract}
Public programs that benefit older individuals, such as Social Security and Medicare, may be changed in the future in ways that reflect an expectation of longer work lives. But do older Americans have the health capacity to work longer? This paper explores this question by asking how much older individuals could work if they worked as much as those with the same mortality rate in the past or as much as their younger counterparts in similar health. Using both methods, we estimate that there is significant additional capacity to work at older ages. We also explore whether there are differences in health capacity across education groups and whether health has improved more over time for the highly educated, using education quartiles to surmount the challenge of changing levels of education over time.
\end{abstract}

\author{
Courtney Coile \\ Department of Economics \\ Wellesley College \\ 106 Central Street \\ Wellesley, MA 02481 \\ and NBER \\ ccoile@wellesley.edu \\ Kevin S. Milligan \\ Vancouver School of Economics \\ University of British Columbia \\ 6000 Iona Drive \\ Vancouver, BC V6T 1L4 \\ CANADA \\ and NBER \\ kevin.milligan@ubc.ca
}

David A. Wise
NBER

1050 Massachusetts Avenue

Cambridge, MA 02138

dwise@nber.org 
The Social Security and Medicare programs face large projected deficits in the decades to come. Many of the reforms that have been suggested to put these programs on firmer financial footing include the expectation that individuals will have longer working lives. For example, the recent National Commission on Fiscal Responsibility and Reform (NCFRR, 2010) called for the Social Security Full Retirement Age (FRA) to be indexed to life expectancy, rising by eight months for each additional year of life expectancy so as to keep the relative share of life spent in work and retirement roughly constant. A recent study of Social Security reform options by the Congressional Budget Office (2010) explored raising the FRA from age 67 to age 68 or 70 and raising the number of years of earnings used in the Social Security benefit formula from 35 to 38 .

A critical question raised by such proposals is whether older workers have the ability to work longer. There are numerous potential impediments to longer work lives. Labor demand is one concern. If older workers are paid more than younger workers but are not more productive, as Hellerstein et al. (1999) suggest, then employers may be reluctant for older workers to extend their work lives. Lahey (2008) and Neumark et al. (2015) find evidence of age discrimination in hiring against older women, which may make it more difficult for older workers to find new work following a job loss or to change jobs. Health is another major area of concern, since most measures of health decline with age. Put simply, are older workers healthy enough to work longer?

This paper explores whether older Americans have the health capacity to extend their work lives. We use two methods to assess capacity to work at older ages. The first effectively asks: if people with a given mortality rate today were to work as much as people with the same mortality rate worked in the past, how much could they work? We make 
calculations based on plots of the relationship between employment and mortality over time, using data from Current Population Survey and the Human Mortality Database from 1977 to 2010, building on earlier work by Milligan and Wise (2012a). For this analysis we focus on men, as sharply increasing rates of women's labor force participation over time make it difficult to interpret the results for women.

The second method asks: if people with a given level of health were to work as much as their younger counterparts in similar health, how much could they work? This approach builds on the work of Cutler et al. (2012), who use this method to explore the ability of workers just beyond the Social Security Early Eligibility Age (EEA) of 62 to work, based on the relationship between health and retirement or disability status for slightly younger workers, those age 57 to 61 . We similarly use data from the Health and Retirement Study (HRS) to estimate the relationship between health and employment for a sample of younger males and females, age 51 to 54 , and use these estimates along with the actual characteristics of older individuals, age 55 to 74 , to project the latter's capacity to work based on health.

We also explore whether health capacity to work varies by education group, as averages for the population as a whole may mask substantial heterogeneity in workers' ability to extend their work lives. We do this first by conducting the Cutler et al. analysis separately by education group. Second, we explore how self-assessed health, a broad summary measure of health, has evolved over time by education group. As we discuss in more detail below, one challenge with such an analysis is that average levels of education are rising over time. As Bound et al. (2014) note, relying on fixed education categories such as high school dropout may be problematic when the share of the population in this 
category is changing substantially. Like Bound et al., we overcome this challenge by creating education quartiles and exploring how health by education quartile has changed over time.

Our central finding is that both methods suggest significant additional health capacity to work at older ages. For the Milligan-Wise method, we estimate that men would work an average of 4.2 additional years between the ages of 55 and 69 if the employmentmortality relationship that existed in 1977 were in effect today. This is an increase of over 50 percent relative to the average 7.9 years currently worked in this age range. This estimate reflects substantially higher employment - 16 percentage points higher at ages 55 to 59,27 points at ages 60 to 64 , and 42 points at ages 65 to 69 - relative to actual 2010 employment rates. Results using this method depend on the base year used for comparison, as both employment and mortality are changing over time - for example, estimated additional work capacity is 1.8 years when using 1995 (roughly the trough of employment in recent years) as the base year. In interpreting these results, we caution that this method implicitly assumes that all gains in life expectancy can translate into longer work lives. If one instead uses the NCFRR's logic that a year of additional life expectancy might translate into eight additional months of work and four additional months of retirement, for example, these values could be multiplied by two-thirds.

Using the Cutler et al. method, we also project that men's employment rates would be higher -4 percentage points higher at ages 55 to 59,17 points at ages 60 to 64 , and 31 points at ages 65 to 69 - than they are now, based on the relationship between employment and health for younger individuals and the actual health of older individuals. Results for women are very similar. These higher employment rates translate into an 
additional 2.5 to 2.8 years of work between the ages of 55 and 69 , estimates of roughly the same magnitude as those generated by the Milligan-Wise method. When we conduct this analysis by education group, we find that estimates of additional work capacity are quite similar across education groups for men, while work capacity rises with education for women. Finally, in our analysis of the evolution of self-assessed health by education quartile, we find that while all groups have experiences health gains over time, workers in the top quartile of education have the largest gains in percentage terms.

In the sections that follow, we first provide some brief background on trends in labor force participation and health in the U.S. Next, we outline our methodology and present the results we obtain using our two main methods, and also report the results of our exploration of changes in health over time by education group. We conclude with a discussion of the implications of our findings.

\section{Trends in Labor Force Participation and Health}

The labor force participation rate for U.S. men and women has varied substantially during the period since World War II, as evident from Figures 1 and 2. For men age 55 to 64, participation fell from 90 percent in 1948 to a low of 66 percent in 1994 before rising again and reaching 70 percent by 2013. For men age 65 and above, trends were similar, with labor force participation falling from 47 percent in 1948 to a low of 16 percent in 1993 and then rising to 24 percent in 2013, a 50 percent increase over the lowest value.

The decline in men's participation over much of the second half of the twentieth century spawned a large literature on retirement. Much of the early literature focused on the effect of Social Security and employer-provided pensions on retirement, as Social 
Security and pensions became more ubiquitous and more generous in real terms over this period. These public and private retirement benefit programs made earlier retirement possible, and also sometimes provided strong incentives to exit the labor force at particular ages, as in the case of many defined benefit (DB) pensions.

More recently, Munnell (2015) discussed the factors that might be responsible for the turnaround in older men's labor force participation over the past two decades. These include: program changes to Social Security (raising the FRA from 65 to 67 over time, removing the earnings test for those below the FRA, and raising the actual adjustment for delayed claiming beyond the FRA); a shift from DB to defined contribution (DC) style pensions, which lack incentives to retire at particular ages; a decline in employersponsored retirement health insurance, which may necessitate staying on the job until reaching Medicare eligibility at age 65; increases in workers' level of education and a shift away from physically demanding jobs; and joint decision-making with (often younger) wives. Munnell also cites improved health and longevity as a contributing factor.

Labor force participation trends for women look very different than those for men because of the large increases over time in participation by women of all ages, including older women. For women age 55 to 64, participation rose steadily from 24 percent in 1948 to 59 percent in 2013. Participation among women age 65 and above rose as well, from 9 percent in 1948 to 15 percent in 2013.

Trends in mortality and health are also of interest and are displayed in Figure 3 for men ages 50 to 75 over the past four decades, based on authors' calculations from the National Health Interview Survey (NHIS) and Human Mortality Database. The well-known age gradient in mortality is evident in this figure, as is the trend over time towards lower 
mortality rates. Whereas in 1970-74, men age 55 experienced an annual mortality rate of one percent, in the 2005-09 period, that mortality rate is not reached until age 61 . Similarly, men age 63 in 1970-74 had a mortality rate of two percent, a rate that applied to men age 70 in 2005-09. Improvements in self-assessed health (SAH) are also evident from the figure, although the data is noisier (due to smaller sample sizes) and the age gradient is less pronounced over the ages 60-70. Roughly 20 percent of men age 52 report themselves to be in fair or poor health in 1972-74; in 2005-09 and 2010-13, it is not until men reach ages 60 to 62 that 20 percent are in fair/poor health; at age 52, only 14 percent are in fair/poor health in these later periods.

In sum, Figure 3 makes evident that health deteriorates with age and that health at any given age has improved over time, while Figure 1 shows that older men's labor force participation fell until the mid 1990s and has been rising in the period since. In the analysis that follows, we effectively bring together these trends in labor force participation and health as we explore how much individuals today could work based on the employment-mortality relationship of the past.

\section{Estimating Health Capacity to Work Using the Milligan-Wise Method}

For the first part of our analysis, which relies on the methodology developed in Milligan-Wise (2012a), we use the relationship between mortality and employment that existed at an earlier point in time along with current mortality data to generate an estimate of individuals' ability to work at older ages. Effectively, this method asks: if people today were to work as much as people with the same mortality rate worked in the past, how much would they work? 
One natural question is why we choose to focus on mortality rather than on another measure of health that might be more closely related to the individual's ability to work, such as whether they are in poor health or have any limitations in their activities of daily living. One answer is that mortality is defined consistently across countries, which is important because this analysis is part of a larger international project. Data on mortality is also available over a long period of time, often for the entire population as part of the government's collection of data on vital events including births, deaths, and marriages, allowing precise estimates of mortality rates at single ages for single years. As one additional source of support for this choice, Milligan and Wise (2012b) show that while there are differences across countries in the level of SAH, there is "a fairly tight withincountry relationship between improvements in mortality and improvements in selfassessed health," suggesting that there is a strong relationship between the two measures.

The mortality data used for this analysis comes the Human Mortality Database, which combines data from the National Center for Health Statistics and the U.S. Census. The employment data is from the March Current Population Survey. The period we consider is 1977 through 2010, with the start year chosen to correspond to that used in Milligan and Wise (2012a). The analysis is quite straightforward, as it requires mapping an employment-mortality curve, which displays the employment rate at each level of mortality for a given year, then repeating this for other years and making some calculations based on comparisons of the different curves. As noted earlier, we conduct this exercise for men only, as the large increases in women's labor force participation over time make it difficult to interpret the results for women. 
Our approach is illustrated in Figure 4, which plots the employment-mortality curve for men in 2010 and in 1977 . In 2010, the one-year mortality rate for 55-year-old men was about 0.8 percent, and the employment rate at this age was 72 percent. In 1977, 49year-old men had a mortality rate of 0.8 percent, while the mortality rate for 55 -year-olds was 1.3 percent. This reflects the mortality improvements over time discussed in the previous section. In 1977, the labor force participation for 49-year-olds was 89 percent. Thus, if men in 2010 had the same employment rate as did men in 1977 with the same mortality rate, the employment rate of 55 year-olds would have been 17 percentage points higher, 89 percent instead of 72 percent.

In Table 1, we extend this exercise through age 69, asking how much more men in 2010 could have worked over the age range 55 to 69 if they had worked as much as men with the same mortality rate worked in 1977 . At age 55, an additional 17 percent of men could have worked, which generates an average 0.17 additional work years (one additional year for 17 percent of 55-year-olds). At age 56, an additional 13 percent of men could have worked for an additional 0.13 work years. Repeating this analysis at each subsequent age through age 69 and cumulating the amounts, we arrive at a total potential additional employment capacity of 4.2 years. This is equivalent on the graph to integrating between the two curves from one vertical line to the next. As the average amount of employment between ages 55 and 69 in 2010 is 7.9 years, an additional 4.2 years would represent a 53 percent increase over the baseline years of work.

It is worth noting that this method implicitly assumes that all mortality gains can translate into additional work capacity. This may not be the case if workers are living longer but are not in good health in those additional years of life. The relationship between 
mortality and morbidity changes over time has been the subject of a number of recent studies. Cutler et al. (2013) argue that functional measures of health are improving, providing strong evidence for compression of morbidity based on measured disability, though disease rates have remained relatively constant so there is less evidence of compression based on disease-free survival rates. Others such as Crimmins et al. (2009, 2010) believe that the period of disabled life is expanding or that evidence is more mixed. As noted above in Figure 3, we find that the share of individuals reporting themselves to be in fair or poor health at a given age has been dropping over time.

A second concern is that it may not be reasonable to expect that an additional year of life would translate into a full additional year of work. The NCFRR, for example, suggests that changes in the Social Security FRA be made so as to keep the share of life spent in work and retirement constant, at two-thirds and one-third, respectively. Using this benchmark, one could multiply the figure above by two-thirds, arriving at an estimate of 2.8 years rather than 4.2 years (for simplicity, we do not make this conversion for the numbers reported below).

Another issue that arises in implementing this method is the choice of year to use for comparison to the present. In Figure 5, we replicate the analysis from Figure 4 but use 1995 as a comparison year rather than 1977 . This year was chosen because it is roughly the trough of labor force participation in the post-war period, as discussed above. At every age, the mortality rate is lower in 2010 than in 1995, consistent with earlier discussions. However, employment rates are higher in 2010 than in 1995 - at age 62, for example, the employment rate was 55 percent in 2010 vs. 43 percent in 1995. Although employment at a given age has increased over time, it has not increased by enough to keep up with 
mortality increases, and for that reason the 1995 employment-mortality curve still lies above that for 2010, although the gap between the two curves is less than that between the 2010 and 1977 curves. Using 1995 as the comparison year, the estimated additional employment capacity from ages 55 to 69 is 1.8 years, which is substantially smaller than the estimate of 4.2 years that we obtain when we use 1977 as the comparison year.

In Figure 6, we show the estimated additional employment capacity as a function of the base year used. For base years close to 2010, the estimated additional employment capacity is small, as we are essentially asking, if men with a given mortality rate in 2010 worked as much as men with the same mortality rate did in, say, 2008, how much would they work; the resulting value is small because neither mortality nor employment changes much over a short period of time. But as shown in the 1995 and 1977 examples, when we look back over a longer period of time, the estimated additional capacity is much larger. This is both because mortality has improved over time, as the 1995 example illustrates, and because employment rates today are lower than they were in the late 1970s and early 1980s (though higher than in the mid-1990s), as seen in the 1977 example.

While we have argued above that it is appealing to use mortality to assess work capacity, it is also valuable to estimate work capacity using other measures of health if appropriate data exists. In the U.S., the existence of the long-running National Health Interview Survey (NHIS) makes this possible. In Figures 7 and 8, we replicate the approach used in Figure 4 with self-assessed health and activity limitation in place of mortality. In these figures, the horizontal axis reflects the share of individuals who report themselves to be in fair or poor health (Figure 7) or the share reporting that they have any activity 
limitations (Figure 8). ${ }^{1}$ We now average data over the 1970 s and 2000s rather than use a single year of data to obtain greater precision, since the sample available through the NHIS is much smaller than the universe of death records used for the mortality analysis.

These figures show the same pattern of health improvement over time that was seen for mortality in Figure 4. For example, in the 1970s, 23 percent of 55-year-olds were in fair or poor health, as compared to 14 percent of 55-year-olds in the 2000s; for activity limitations, the equivalent figures are 25 percent for the 1970 s and 16 percent for the 2000s. When we use the employment-health curves from the 1970s and 2000s to generate an estimate of work capacity using the method shown in Table 1, we find that the additional capacity between ages 55 and 69 is 5.1 years using self-assessed health and 4.9 years using activity limitations. These values are slightly larger than the 4.2 years we found using mortality as our measure of health between 1977 and 2010. In the remaining discussion, we focus on our mortality estimates.

In short, estimates based on the Milligan-Wise method suggest a significant amount of additional work capacity. We estimate that the additional capacity from ages 55 to 69 is 4.2 years using the 1977 employment-mortality curve as a point of comparison, or 1.8 years using 1995 as the base year. To change the assumption that an additional year of life expectancy translates into an additional year of work capacity, one can apply a fractional factor to these estimates - using the logic of the NFCRR that the share of life spent in work and retirement should remain roughly constant, for example, might suggest multiplying these values by two-thirds.

\footnotetext{
${ }^{1}$ We code respondents as activity-limited if they report not being able to perform major activity, are limited in amount/kind of major activity, or are limited in other activities or limited in any way.
} 
Another point of interest is what this method suggests about the ability of older individuals to work at specific ages. This can be inferred from the bottom of Table 1, using 1977 as the comparison year. This analysis suggests that at ages $55-59$, an additional $16 \%$ of men could be employed (averaging additional employment capacity values for ages 5559); at ages 60-64 and 65-69, this figure rises to 27 percent and 42 percent, respectively. These estimates can be compared to the results we generate using the next method.

\section{Estimating Health Capacity to Work Using the Cutler et al. Method}

We now turn to our second method of estimating health capacity to work, employing the approach developed in Cutler et al. (2013). In this method, we essentially ask: if older individuals in a given state of health worked as much as their younger counterparts, how much would they work? Implementing this method involves a two-step process. First, we run regressions to estimate the relationship between health and employment, using a sample of individuals young enough that their employment decisions should not be affected by the availability of Social Security benefits. We choose to focus on those age 51-54, who are still many years away from the Social Security EEA, with the age 54 cutoff chosen largely for ease of comparison with the other studies in this volume. For the second step, we combine the regression coefficients from step one along with the actual characteristics of individuals age 55 to 74 to predict the older individuals' ability to work based on health.

The data used in the analysis is the Health and Retirement Study (HRS). The HRS began in 1992 as a longitudinal study of individuals then age 51-61 and their spouses, with biannual interviews; in the years since, the study has been refreshed with younger cohorts 
in order to provide a representative survey of individuals above age 50. Currently data through 2012 (wave 11) is available; we use data from waves 2-11 in the analysis, starting with wave 2 because some of the health variables we use are not available in wave 1 . The HRS is ideally suited for a study such as this one because of the rich data on health, as well as data on employment and demographics. In our regressions, we start at age 51 since the HRS is a representative sample for this group. We have a sample of roughly 5,700 male and 9,900 female person-year observations for the regressions; a further 52,000 male and 64,000 female person-year observations are used in our simulations of work capacity.

We estimate regressions of the following form:

$$
\text { Employment }_{i}=\beta_{0}+\beta_{1} \text { health }_{i}+\beta_{2} X_{i}+\varepsilon_{i}
$$

where employment is a dummy equal to 1 if the individual is employed and health is a comprehensive set of health measures, including dummy variables for self-reported health status, limitations on physical activity, limitations on activities of daily living (ADLs) and instrumental activities of daily living (IADLs), individual health conditions, being over- or underweight, and being a current or former smoker. We also include variables for educational attainment, race, marital status, occupation, health insurance, and pension coverage, as well as wave fixed effects to capture any time trends in employment. We estimate this equation as a linear probability model.

We estimate an alternative version of this regression model where the full set of health variables is replaced by a single health index value, developed using the approach described in Poterba et al. (2013). The idea is to construct a health index based on 27 questions, including self-reported health diagnoses, functional limitations, medical care usage, and other health indicators. To do so, one first obtains the first principal component 
of these indicators, which is the weighted average of indicators where the weights are chosen to maximize the proportion of the variance of the individual health indicators that can be explained by this weighted average. The estimated coefficients from the analysis are then used to predict a percentile score for each respondent, referred to as the health index. An individual's health index value typically will vary by HRS survey wave, as updated health information is incorporated. As Poterba et al. (2013) demonstrate, the health index is strongly related to mortality and future health events such as stroke and diabetes onset, though not to future new cancer diagnoses.

It is worth noting some of the key assumptions underlying our analysis. First, we assume that there are no unmeasured or omitted dimensions of health. If there were, health might be declining more rapidly with age than reflected in the health variables we have, and our estimates of ability to work at older ages could be overstated. We aim to minimize this concern by including a comprehensive set of health variables, as well as by using a health index that is likely a good reflection of overall health. Second, our approach implicitly assumes that the health-employment relationship that exists for younger individuals (age 51-54) is the same as that for older individuals (age 55-74). For example, if younger workers were concentrated in white collar jobs and older workers in blue collar jobs, then it might be easier for a younger worker with a health problem to continue working than it would be for an older worker with the same health issue; if an issue like this were present, it would lead us to overstate the ability of older individuals to work. Finally, it will pose something of a problem if there is a large amount of "discretionary" (non-health-related) retirement among our sample of younger individuals, as this will 
cause us to estimate a lower health capacity to work than what might actually exist. We have chosen a relatively young sample for the estimation to try to avoid this problem. ${ }^{2}$

Summary statistics for the male and female samples are shown in Tables $2 \mathrm{a}$ and $2 \mathrm{~b}$. The share of men that is employed falls from 79 percent at ages 51-54 to 75 percent at ages 55-59, 59 percent at ages 60-64, 39 percent at ages 65-69, and 27 percent at ages 70-74. Employment rates for women are roughly ten percentage points lower in each age group. The health measures show a decline in health with age. The share of men in fair or poor health rises from 22 percent at ages 51-54 to 27 percent at ages 70-74. Values for women are similar but slightly higher, 24 percent at ages 51-54. This reflects the known result that women live longer but report themselves to be in worse health.

Continuing to some of the other health measures, the share of men with more than one limit on their physical activity rises from 33 percent at ages 51-54 to 48 percent at ages 70-74, while values for women are substantially higher, 46 percent at ages 51-54, but show a somewhat flatter age gradient. ${ }^{3}$ The share of individuals with limitations in ADLs rises from 10 percent to 12 percent for men across the five age categories, and from 10 to 15

\footnotetext{
2 We also acknowledge that health may be endogenous in the regressions we run, if employment status has a causal effect on health. Whether this is the case, and what the sign of the effect is, is a subject of debate in the literature. Charles (2004) and Johnston and Lee (2009) find positive effects of retirement on mental health, while Bound and Waidmann (2007) find some evidence of a positive effect on physical health for men. By contrast, in their study of the mortality effects of reduced Social Security payments to the "notch" generation, Snyder and Evans (2006) note that younger cohorts responded to the benefit cut by increasing their postretirement work effort with positive effects on mortality, suggesting that moderate work at older ages may be beneficial for health. Unfortunately, without more clarity from the literature it is difficult to sign the potential bias from ignoring this potential endogeneity. Estimating the causal effect of retirement on health is a fruitful area for future work.

3 The full set of activities includes: walking one block, walking several blocks, jogging for one mile, sitting for two or more hours, climbing stairs, stooping/kneeling/crouching, carrying weights over ten pounds, and picking up a dime. Individuals may be coded as having difficulty with one or more than one of these activities. The relatively large share of the sample with at least one limit on physical activity may be due in part to the inclusion of jogging one mile, which is a particularly difficult task for many older individuals.
} 
percent for women; the share with limitations in IADLs are fairly flat with respect to age for men but rise from 6 to 10 percent for women. ${ }^{4}$ Finally the share of individuals with diagnosed medical conditions also rises with age. Arthritis and high blood pressure are the most common issues, rising for men from 27 and 38 percent at age 51-54 to 52 and 56 percent at age 70-74. Potentially more serious health conditions such as cancer and stroke also rise dramatically with age. The relevance of these statistics for our analysis is that they show that health deteriorates with age, so if our regressions suggest a strong relationship between health and employment, then the predicted share of individuals that is employed (estimated in the second step of our analysis) will decrease with age, as health declines.

The results of estimating our regression model are shown in Tables 3a and $3 \mathrm{~b}$ for the all health variables and health index versions of our model, respectively. Table 3a shows that there are large and statistically significant effects of many of the health variables on employment. For example, relative to men in excellent health, men in poor (fair) health are 20 (9) percentage points less likely to be employed; for women, these values are 18 and 7 points. Having ADL or IADL limitations lowers men's employment by 20 and 14 points, respectively, and lowers women's employment by 13 points. Having limits on physical activity has no significant effect on employment, perhaps because these issues are more widespread and consequently less severe. Some of the individual health conditions are associated with statistically significant decreases in the probability of employment of up to 10 percentage points, such as having experienced a stroke, psychiatric condition, or diabetes.

\footnotetext{
${ }^{4}$ ADLs include: dressing, walking across the room, bathing, eating, and getting in/out of bed; IADLs include managing meals, groceries, and medication.
} 
In the version of the model with the health index, Table $3 b$, the index is strongly associated with employment. A ten-percentage point increase in the index (e.g., being at the $60^{\text {th }}$ rather than $50^{\text {th }}$ percentile of health) raises the probability of employment by 4.8 percentage points for men and by 3.4 percentage points for women. We believe that this suggests that the index functions well as a summary statistic for health. This is reassuring, because in some cases - for example, in a number of the other countries participating in the larger project of which this paper is part - there is insufficient data to estimate models like those shown in Table 3a. We focus on the results from Table $3 \mathrm{~b}$ in the discussion below.

In Table 4, we report the results of our simulation exercise. This table shows, for men and women in 5-year age groups from age 55 to 74, the share employed, the predicted share employed (calculated as described above by combining the coefficients from the regression analysis and the actual characteristics of these individuals), and the difference between these, which we term the estimated additional work capacity. For ease of exposition, key values are also reported in Figure 9 and 10. Focusing on the health index results, we predict the share of men employed to be 78 percent at ages 55-59, 76 percent at ages 60-64, 70 percent at ages 65-59, and 66 percent at ages 70-74. These projections decline with age because health declines with age and our regression coefficients reflect a strong association between health and employment. However, the share of men that is actually working declines more quickly with age than do our predictions, from 75 percent at ages 55-59 to 59 percent, 39 percent, and 27 percent in the older age groups. As a result, we estimate that additional capacity to work is substantial and rising sharply with age, from 4 percent at ages 55-59 to 17 percent at ages 60-64, 31 percent at ages 65-69, and 39 percent at ages 70-74. Results using the model including individual health variables are 
quite similar. In terms of the results for women, while both the predicted and actual share working are somewhat lower than those for men, the estimated work capacity numbers are very similar, at 5 percent, 17 percent, 29 percent, and 37 percent across the four age groups.

How do these results compare to those obtained using the Milligan-Wise method? As noted earlier, that analysis (done for men only) suggested that employment would be 16 percentage points higher at ages 55-59, 27 points higher at ages 60-64, and 42 percentage points higher at ages 65-69 if people today worked as much as people with the same mortality rate worked in 1977 . These values are 10-12 percentage points higher than the numbers found here. We can also compare the implied total additional years of work between ages 55 and 69. Using the Milligan-Wise approach, we obtained a value of 4.2 years, using 1977 as the base year. Here, assuming additional employment of 5/17/29 percent at ages 55-59/60-64/65-69, we estimate that men would work an additional 2.6 years on average. As noted above, however, the numbers from the Milligan-Wise method would be smaller if one used a more recent year for comparison or assumed that only some share of the gains in mortality would translate into increases in employment, so making either or both of these adjustments would make the two sets of numbers more similar. Given how different the two methods employed in this paper are, it is striking and perhaps somewhat reassuring that they generate results of roughly similar magnitude.

One potential concern with the analysis to date is that our estimates reflect population averages, which may mask substantial heterogeneity in the ability to work longer. In particular, less educated and lower income individuals may have less potential to extend their work lives because they are in worse health or have jobs where 
employment is more sensitive to health status. In the case of the Milligan-Wise analysis, it was unfortunately not possible to explore how the employment-mortality relationship has changed over time by education group or income group because U.S mortality records do not include that information. ${ }^{5}$

For the present analysis, however, it is possible to augment our basic results with an analysis that estimates work capacity separately by education. We re-estimate the regression model separately by education group, which allows the relationship between employment and health to differ by education group - as might be the case, for example, if workers with less education are concentrated in blue-collar jobs where it is more difficult to continuing working once one experiences a health problem than it would be in the white-collar jobs held by more highly-educated workers. ${ }^{6}$

Our simulations of work capacity by education group are shown in Tables $5 \mathrm{a}$ and $5 \mathrm{~b}$ and in Figures 11 and 12. Although the actual and predicted share working varies substantially by education group - for example, the actual and predicted share working among men ages 55-59 are 85 and 89 percent for college graduates vs. 61 and 63 percent for high school dropouts - the estimates of additional work capacity are fairly similar across education groups for men. Specifically, estimated additional work capacity for men at ages 55-59 is in the range of 2-6 percent for all education groups, and similarly is 15-21 percent at ages 60-64, 28-35 percent for ages 65-69, and 35-42 percent at ages 70-74,

\footnotetext{
${ }^{5}$ Brown et al. (2002) show that mortality rates are higher for less educated groups, based on an analysis of data from the National Longitudinal Mortality Study. Unfortunately, this data set does not have sufficient sample size and years of coverage to be used for our analysis.

${ }^{6}$ We also generate results by education in a simpler way, continuing to use a common set of regression coefficients for all education groups but reporting the actual share working, predicted share working, and estimated additional work capacity separately by education group. The results of this exercise, which are shown in Tables $6 \mathrm{a}$ and $6 \mathrm{~b}$, are qualitatively similar to those in Tables $5 \mathrm{a}$ and $5 \mathrm{~b}$, though differences across education groups for women are only about two-thirds as large.
} 
using the health index model estimates. We report the implied total additional years of work between ages 55 and 69 on Table 7, and show that the value for high school dropouts (2.3 years) is similar to that for college graduates ( 2.5 years), though high school graduates have a somewhat larger capacity ( 3.1 years). Thus there is no clear pattern in estimated additional work capacity with respect to education for men. On Table $5 \mathrm{~b}$, we find that less educated women consistently have lower estimated additional work capacity - for example, among those ages 65-69, additional work capacity is 24 percent for high school dropouts vs. 36 percent for college graduates. As shown on Table 7, the additional years of work capacity is 2.1 for female high school dropouts, 2.5 for high school graduates, and 3.1 for college graduates. Thus overall the evidence is somewhat mixed, with no differences in estimated work capacity by level of education for men but greater estimated capacity to work among more educated women.

\section{Changes in Self-Assessed Health by Education Level Over Time}

We undertake one final analysis to explore potential heterogeneity in health capacity. Several recent studies, including Waldron (2007), Bosworth and Burke (2014), and National Academies of Sciences (2015), find that life expectancy has been growing more rapidly over time for high-income groups than for low-income groups. Is the same true for other key health measures such as self-assessed health (SAH)? In this section of the paper, we aim to explore how SAH has evolved over time for those with different levels of socioeconomic status (SES).

To explore such a question, one first needs a measure of SES that can be found in a data set with information on health over a long period of time. In theory, lifetime income 
(used by Waldron (2007) and others in studies of mortality) is an attractive measure, but most health data sets will at best have current income, which may be only loosely related to lifetime income, especially for older individuals, many of whom have retired. Education thus may be preferred as a measure that is both widely available and highly correlated with lifetime income. However, using education introduces its own set of problems, as pointed out by Bound et al. (2014). Responding to Olshansky et al. (2012), who estimate that white male high school dropouts experienced sharply decreasing life expectancy over the period 1990 to 2008, Bound et al. counter that this finding can arise from ignoring rising levels of education over time. As more recent cohorts have far fewer high school dropouts than past cohorts, individuals in recent cohorts who are high school dropouts may be more negatively selected relative to high school dropouts in earlier cohorts. Failing to account for this can generate misleading results. Bound et al. suggest correcting for this by using education quartiles, which provide consistent groups to analyze over time (as the lowest quartile of education is always the lowest quartile, whether dominated by those with an $8^{\text {th }}$ grade education or high school graduates).

We implement this suggestion and estimate trends in SAH by education quartile. Figure 13 shows the distribution of educational attainment for men by birth cohort. For cohorts reaching age 50 in 1950 (born in 1900), the median individual had an $8^{\text {th }}$ grade education and about 70 percent of individuals had less than a high school education. Thereafter, educational attainment rises rapidly. By 1965, the median 50-year-old is a high school graduate, and by 1996, the median 50 -year-old has some college. Since the late 1990s, however, there is some evidence of a reversal in this trend. 
Figure 13 may be used to illustrate how the education quartiles are defined. For the 1950 cohort of 50-year-olds, for example, the lowest quartile includes all of those with a kindergarten to grade 4 education. The group with grade 5 to 7 education extends beyond the first quartile, so we randomly sample from among this group to fully populate the lowest quartile. The next quartile includes the rest of the grade 5 to 7 group and most of the grade 8 group, again using randomly sampling to determine which will be allocated to the $2^{\text {nd }}$ education quartile and which to the $3^{\text {rd }}$. The $3^{\text {rd }}$ quartile largely consists of the rest of the grade 8 group, all those with grade 9 to 11 education, and about half of the high school graduates, while the top quartile includes the rest of the high school graduates and everyone with some college or more education. In the 2000 cohort of 50-year-olds, the lowest quartile includes some high school graduates and everyone with less than high school, while the top quartile includes most of the college graduates and everyone with graduate education. The key point is that the educational composition of the population changes substantially over time, so we focus on education quartiles to have a consistent measure of the less and more educated. The trends for women, shown in Figure 14, are fairly similar, with women having somewhat more high school graduates in the early years and a leveling off rather than retrenchment in educational attainment in recent years.

In Figure 15, we plot the share of men who report themselves to be in fair or poor health by age for three different time periods, 1972-85, 1986-95, and 1996-2013, reporting results separately by education quartile. The data for these figures comes from the National Health Interview Survey, and data is aggregated over many years for greater precision. The familiar negative relationship between age and health is evident from the figures, as is the fact that health is better among the higher education quartiles. What 
interests us particularly is the evolution of SAH over time across education quartiles. We find that all quartiles experience improvements in health over time. However, as a percentage change from the 1972-85 values, the highest education group experiences the largest improvements in health over time, as reported in Table 8. Averaging across ages 50 to 75 , the share of men in fair/poor health in the highest education quartile drops by 39 percent between the earliest and latest period, vs. by 24 percent for the $3^{\text {rd }}$ quartile, 23 percent for the $2^{\text {nd }}$ quartile, and 19 percent for the $1^{\text {st }}$ quartile. The pattern for women, shown in Figure 16 and summarized in Table 8, is similar - they experience a 34 percent average improvement in the top education quartile and a 15 percent improvement in the bottom quartile.

In sum, as other studies have found for life expectancy, gains in SAH appear to be accruing disproportionately to high-SES individuals. Although there is no direct link to employment in this section of our analysis, these findings suggests that over time, it may be becoming easier for higher-SES individuals to extend their work lives because their health is improving more rapidly than that of lower-SES individuals.

\section{Discussion and Conclusion}

Possible future changes to Social Security and other programs that benefit the elderly are likely to include the expectation that people will work longer. Do older individuals have the health capacity to do so? In this paper we have explored this question using two methods. We first ask, if people with a given mortality rate today worked as much as those with the same mortality rate in the past, how much could they work? Next we ask, if older individuals with a given health status worked as much as their younger 
counterparts, how much could they work? Both methods suggest that there is substantial additional work capacity. Evaluating work capacity purely on the basis of health, our analysis suggests that the share of older men working at ages $60-64$ could be 17-27 percentage points higher than it is today, while the share working at ages 65-69 could be 31-42 percentage points higher; estimates for women are similar. Our analysis also implies that the average number of years worked between ages 55 and 69, currently 7.9, could rise by at least 2.5 years, even allowing for a portion of recent life expectancy increases to be channeled into leisure.

We find mixed evidence regarding the heterogeneity of work capacity, with greater work capacity among more educated women as compared to less educated women, but no such finding for men. We further find that gains in SAH over time, measured in percentage terms, have been concentrated among high-education groups. Although this finding is not linked directly to employment in our analysis, it suggests that more highly educated individuals may be finding it easier to extend their work lives.

As noted throughout the paper, there are many assumptions and caveats that apply to our analysis, such as the concern that mortality may not be perfectly correlated with work ability or that we do not directly address the possible endogeneity of health. Nonetheless, our basic conclusion that most people are healthy enough to work longer than they do now seems likely to be sound. As illustrated on Figure 1, although older men are working more than they used to, labor force participation rates today are still well below pre-1980 levels for 55-64 year olds (and below pre-1970 levels for those 65 and above). This fact, along with the declines in mortality and poor health over time seen in Figure 3, suggests that many people can work longer. The Milligan-Wise approach offers one way to 
quantify the additional work capacity that is suggested by these coincident trends in employment and health. Similarly, the summary statistics in Table 2 show that employment declines rapidly as workers reach their 60 s, while health declines steadily but quite gradually with age. The fact that health does not plummet along with employment suggests that there are reasons other than health for the employment decline, such as the availability of Social Security. The Cutler et al. approach offers a means to estimate how much of a decline in employment with age we might expect based solely on declining health. The exact values we estimate for potential increases in employment rates or years of work are less important than the overall conclusion that using two very different approaches, we consistently find that individuals are healthy enough to work longer.

It is important to recall that our analysis does not address other factors that may affect workers' ability to work longer, such as cyclicality in labor demand or age discrimination, to the extent that these factors matter more for today's older workers than they did for workers with the same mortality rate in the past (Milligan-Wise method) or for younger workers (Cutler et al. method). It is also useful to recall that our work addresses the work capacity of the population overall, not that of any given individual. Even when the health of the population is improving, there will always be individuals that are too sick to work. It is important for policy makers to consider the needs of such individuals when making policy decisions - for example, by providing a well-designed disability insurance program. Finally, it is critical to reiterate that our estimates should not be taken as a reflection of how much older workers "should" work. As noted above, the Milligan-Wise method implicitly assumes that all life expectancy gains can be translated into additional years of work. This may not be the case, and even if it is possible it may not be a socially 
desirable outcome, since leisure time has value as well. We intend for our analysis to contribute to the discussion about relatively modest changes to Social Security and related policies. Are older workers healthy enough to work another year or two if they must? We believe that for a majority of older workers, our results suggest that the answer is yes. 


\section{References}

Bosworth, B. P. and K. Burke (2014). "Differential Mortality and Retirement Benefits in the Health and Retirement Study," Brookings Institution working paper.

Bound, John, Arline Geronimus, Javier Rodriguez, and Timothy A. Waidmann (2014). “The Implications of Differential Trends in Mortality for Social Security Policy," Michigan Center for Retirement Research Working Paper 2014-314.

Bound, John and Timothy Waidmann (2007). "Estimating the Health Effects of Retirement," Michigan Retirement Research Center working apper 2007-168.

Brown, Jeffrey R., Jeffrey B. Liebman, and Joshua Pollet (2002). “Appendix: Estimating Life Tables That Reflect Socioeconomic Differences in Mortality," in The Distributional Aspects of Social Security and Social Security Reform, Martin Feldstein and Jeffrey B. Liebman, eds. Chicago: University of Chicago Press.

Charles, Kerwin (2004). "Is Retirement Depressing? Labor Force Inactivity and Psychological Well-Being in Later Life," Research in Labor Economics 23: 269-299.

Congressional Budget Office (2010). Social Security Policy Options. Washington, D.C.

Crimmins, Eileen M., Mark D. Hayward, Aaron Hagedorn, Yasuhiko Saito, and Nicolas Brouard (2009). "Changes in Disability-Free Life Expectancy for Americans 70 Years Old and Older," Demography 46(3):627-646.

Crimmins, Eileen M. and Hiram Beltran-Sanchez (2010). "Mortality and Morbidity Trends: Is There Compression of Morbidity" Journal of Gerontology: Social Sciences 66B(1):75-86.

Cutler, David M., Ellen Meara, and Seth Richards-Shubik (2012). "Health and Work Capacity of Older Adults: Estimates and Implications for Social Security Policy," mimeo.

Cutler, David M., Kaushik Ghosh, and Mary Beth Landrum (2014). "Evidence for Significant Compression of Morbidity in the Elderly U.S. Population," in Discoveries in the Economics of Aging, David A. Wise, ed. Chicago: University of Chicago Press.

Hellerstein, Judith K., David Neumark, and Kenneth R. Troske (1999). "Wages, Productivity, and Worker Characteristics: Evidence from Plant-Level Production Functions and Wage Equations," Journal of Labor Economics 17(3): 409-446.

Johnston, David W. and Wang-Sheng Lee (2009). "Retiring to the Good Life? The ShortTerm Effects of Retirement on Health," Economic Letters 103(1):8-11.

Lahey, Joanna N. (2008). “Age, Women, and Hiring: An Experimental Study,” Journal of Human Resources 43(1):30-56. 
Milligan, Kevin S. and David A. Wise (2012a). "Health and Work at Older Ages: Using Mortality to Assess the Capacity to Work Across Countries," NBER Working Paper 1822.

Milligan, Kevin S. and David A. Wise (2012b). "Introduction and Summary," in Social Security Programs and Retirement Around the World: Historical Trends in Mortality and Health, Employment, and Disability Insurance Participation and Reforms, David A Wise, ed. Chicago: University of Chicago Press.

Munnell, Alicia H. (2015). “The Average Retirement Age - An Update,” Center for Retirement Research at Boston College Issue Brief Number 15-4, March.

National Commission on Fiscal Responsibility and Reform (2010). The Moment of Truth: Report of the National Commission on Fiscal Responsibility and Reform. Washington, D.C.: White House.

National Academies of Sciences, Engineering, and Medicine (2015). The Growing Gap in Life Expectancy by Income: Implications for Federal Programs and Policy Responses. Report of the Committee on the Long-Run Macroeconomic Effects of the Aging U.S. Population-Phase II. Washington, D.C.: The National Academies Press.

Neumark, David, Ian Burn, and Patrick Button (2015). "Is It Harder for Older Workers to Find Jobs? New and Improved Evidence from a Field Experiment," National Bureau of Economic Research Working Paper 21669, October.

Olshansky, S. Jay, Toni Antonucci, Lisa Berkman, Robert H Binstock, Axel Borsch-Supan, John T Cacioppo, Bruce A Carnes, Laura L Carstensen, Linda P Fried, Dana P Goldan, James Jackson, Martin Kohli, John Rother, Yuhui Zheng, and John Rowe (2012). "Differences in Life Expectancy Due to Race and Educational Differences Are Widening and Many May Not Catch Up," Health Affairs 31(8):1803-1813.

Poterba, James, Steve Venti, and David A. Wise (2013). "Health, Education, and the PostRetirement Evolution of Household Assets," paper prepared for the RAND Conference on Health, Aging, and Human Capital.

Snyder, Stephen E. and William N. Evans (2006). "The Effect of Income on Mortality: Evidence from the Social Security Notch," The Review of Economics and Statistics 88(3):482495.

Waldron, Hilary (2007). "Trends in Mortality Differentials and Life Expectancy for Male Social Security-Covered Workers, by Socioeconomic Status," Social Security Bulletin 67(3). 
Figure 1: Men's Labor Force Participation, Ages 55-64 and 65+, 1948-2013

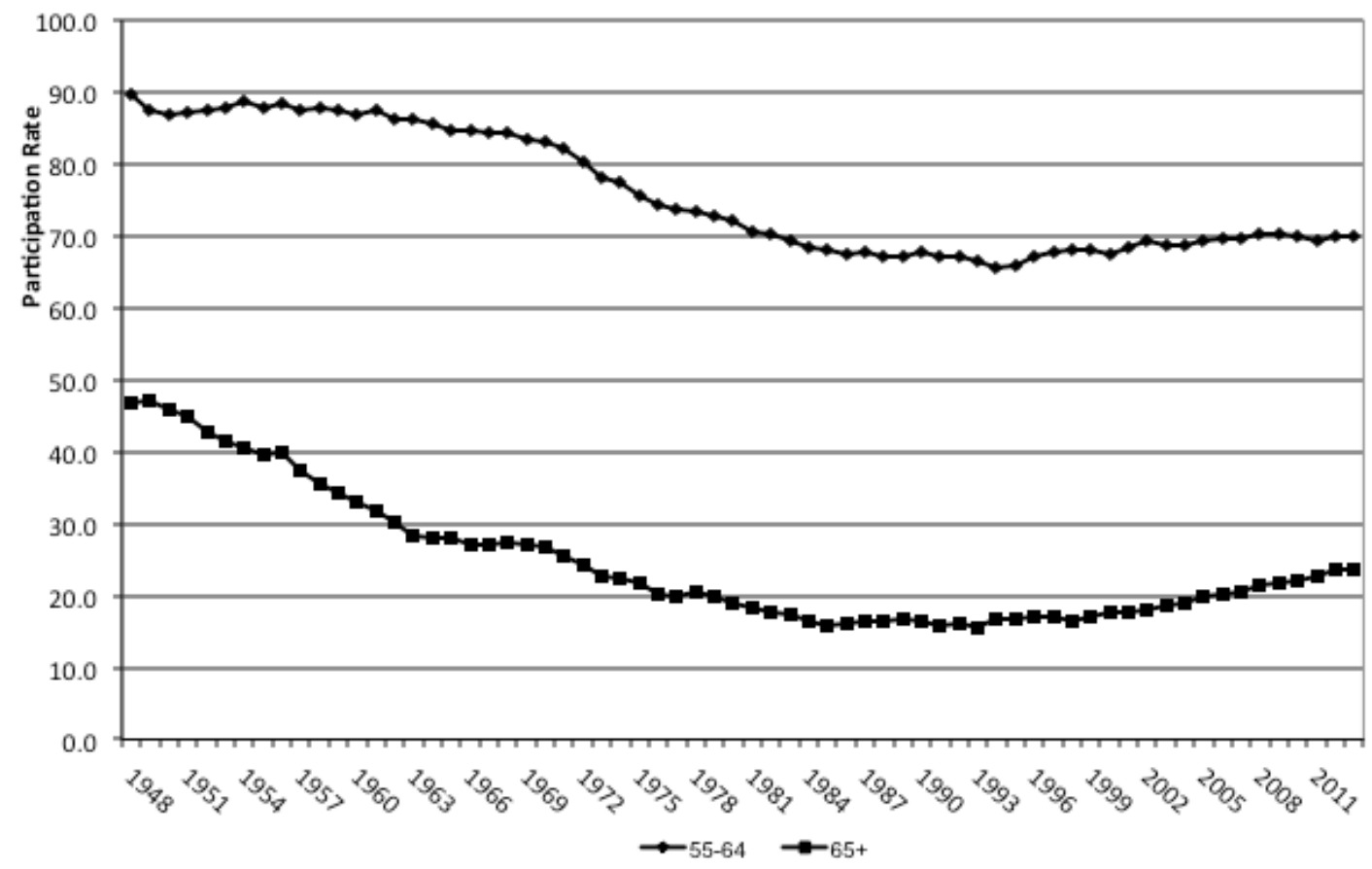

Source: Bureau of Labor Statistics (series LNU01300190 and LNY01300199).

Figure 2: Women's Labor Force Participation, Ages 55-64 and 65+, 1948-2013

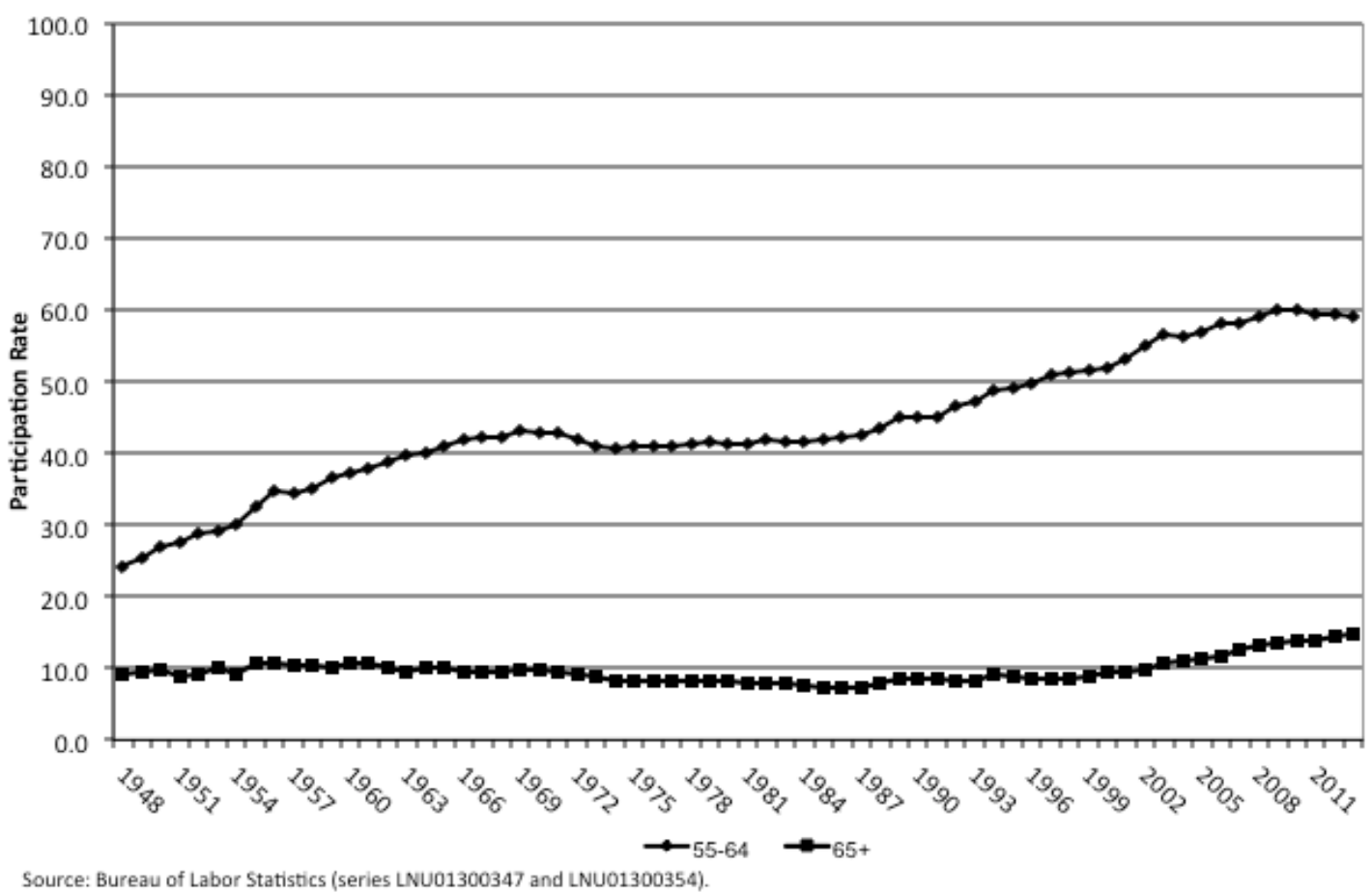



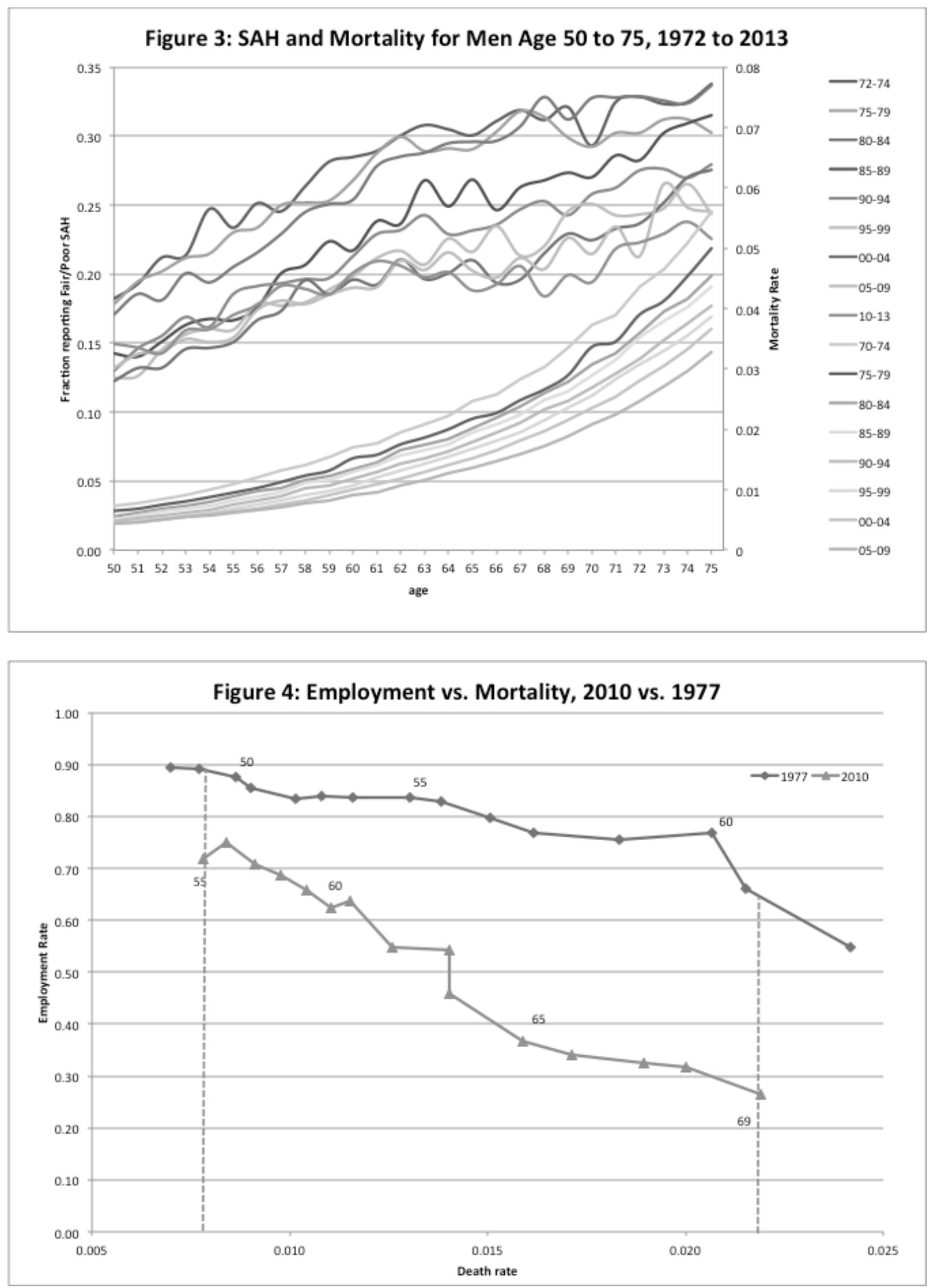

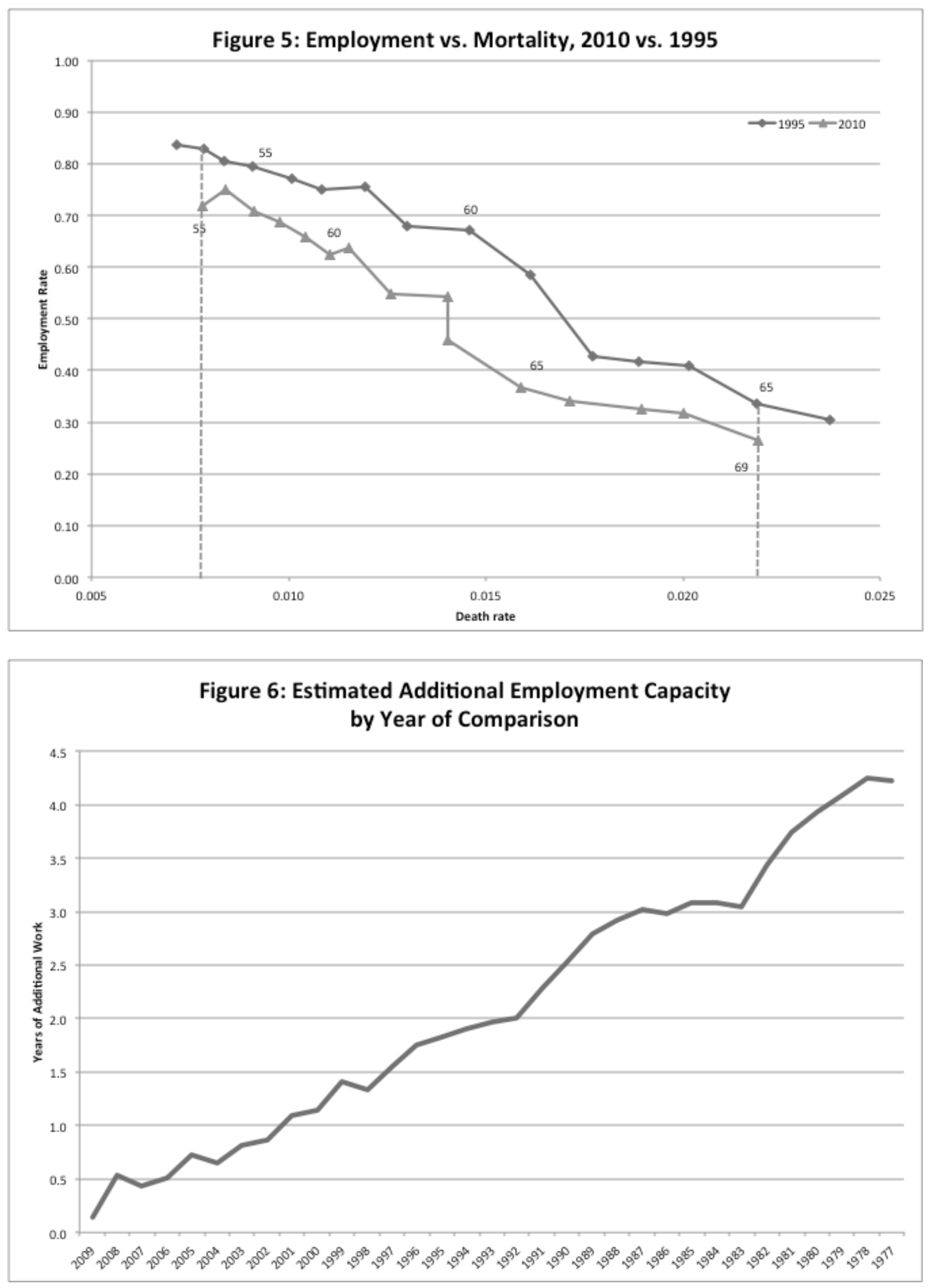

31 

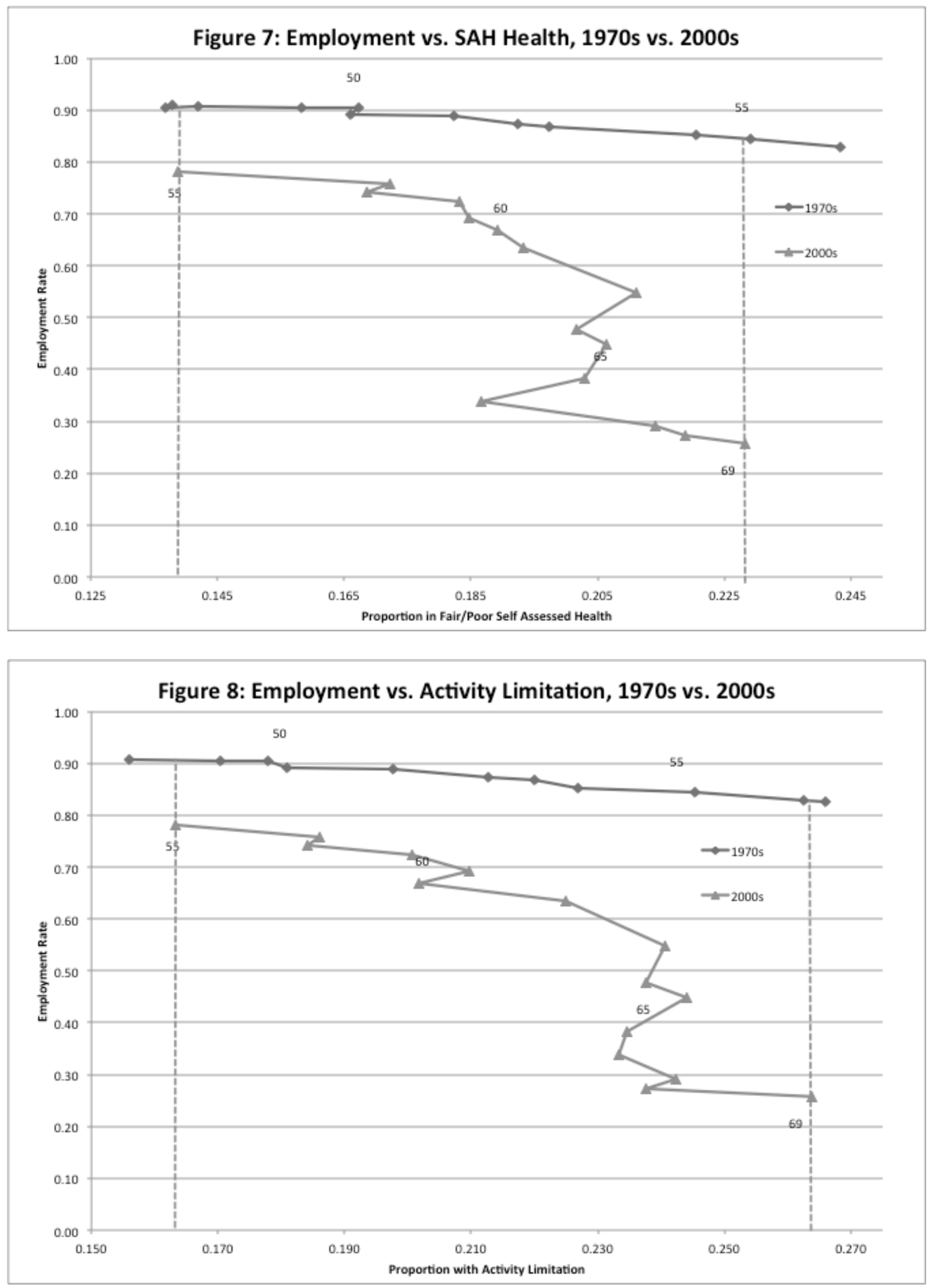

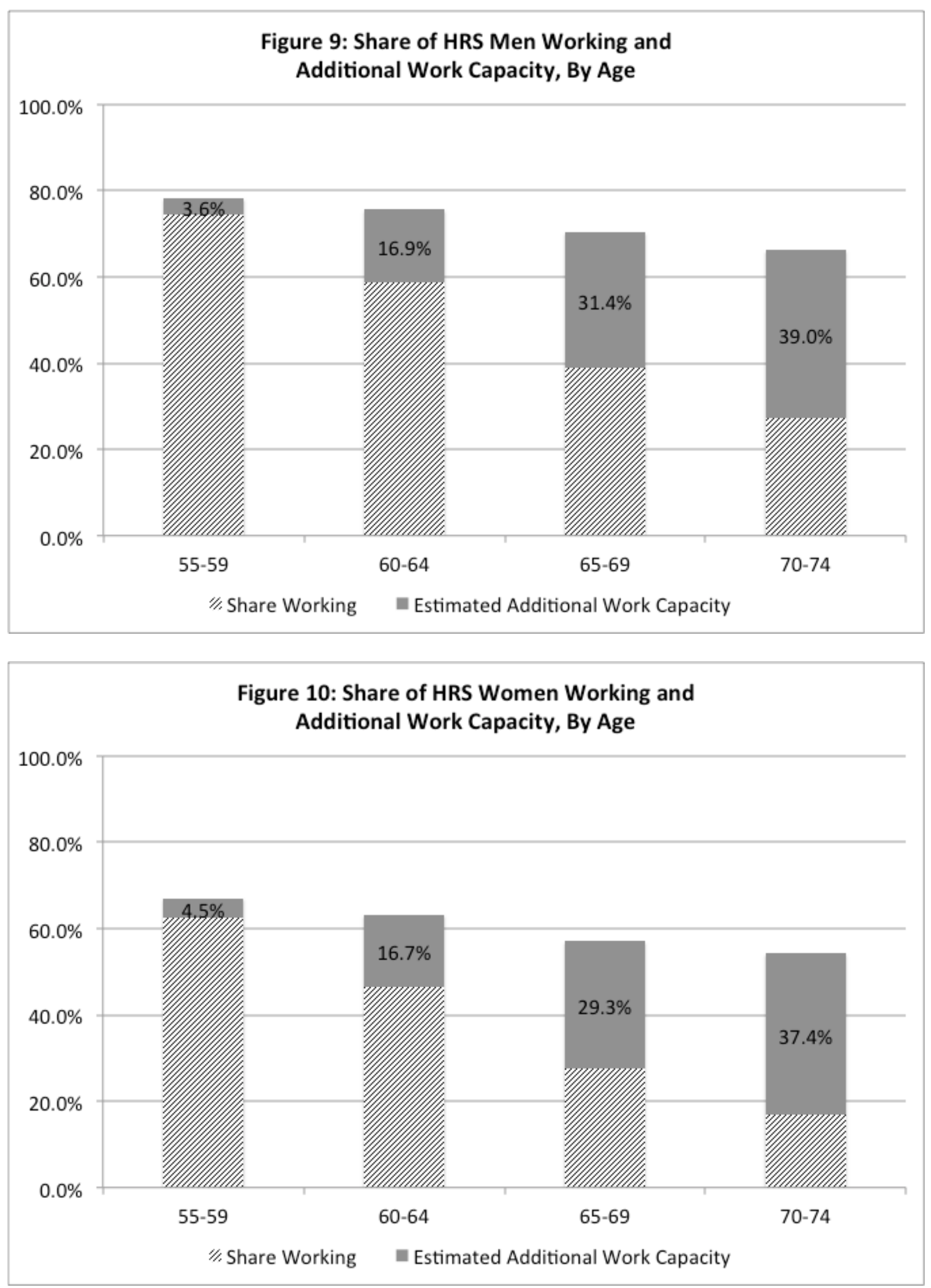

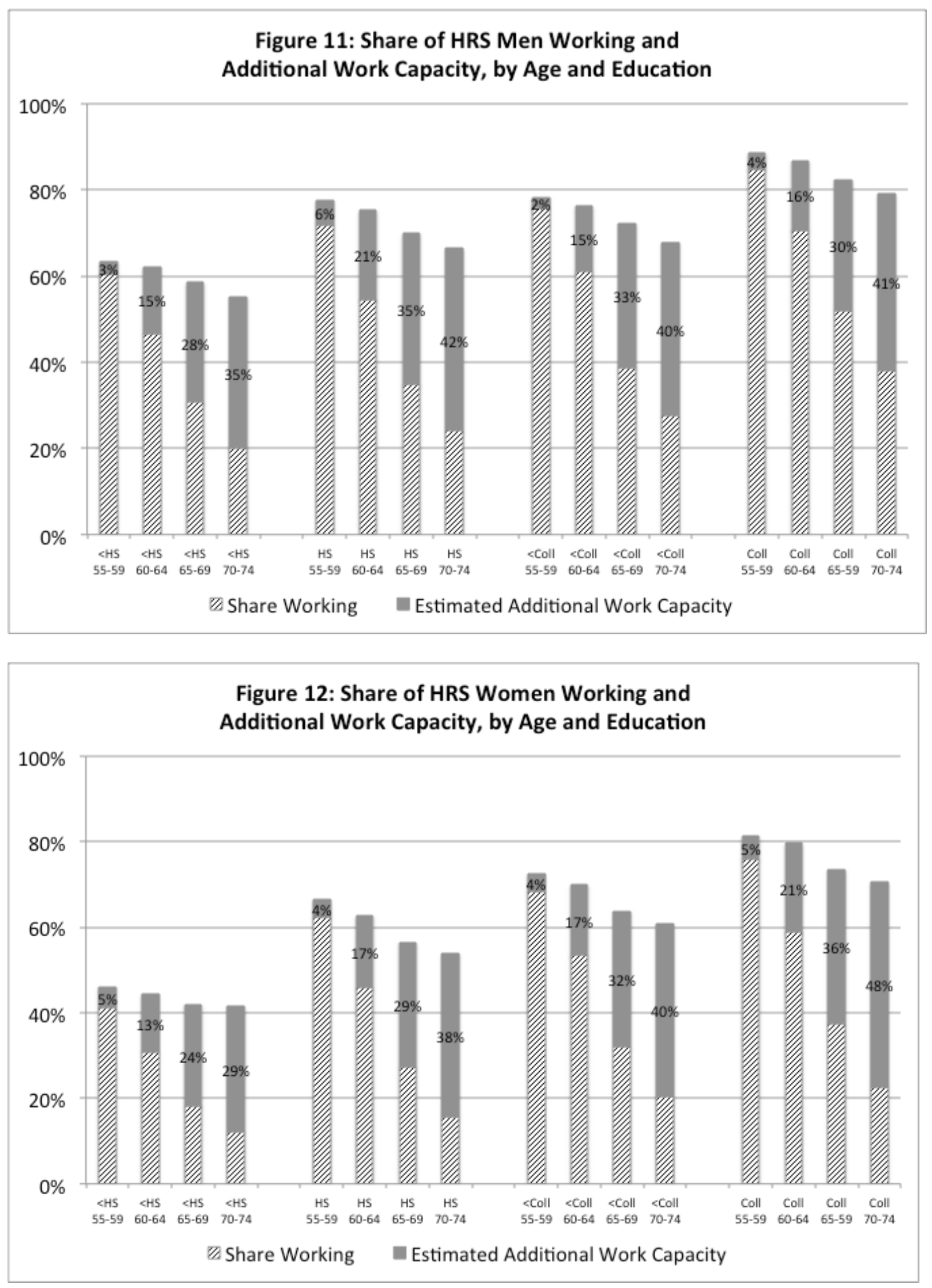


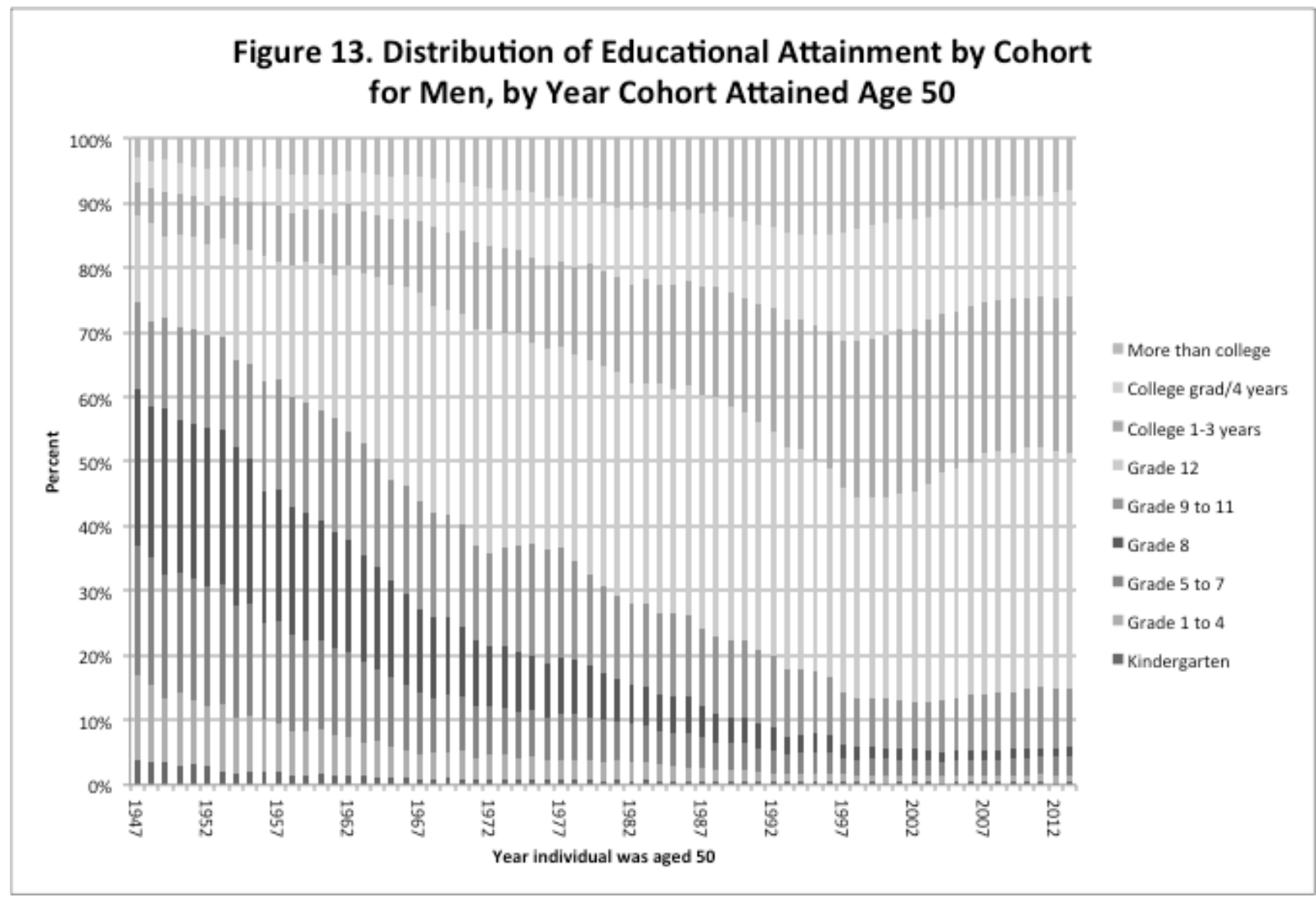

Figure 14. Distribution of Educational Attainment by Cohort for Women, by Year Cohort Attained Age $\mathbf{5 0}$

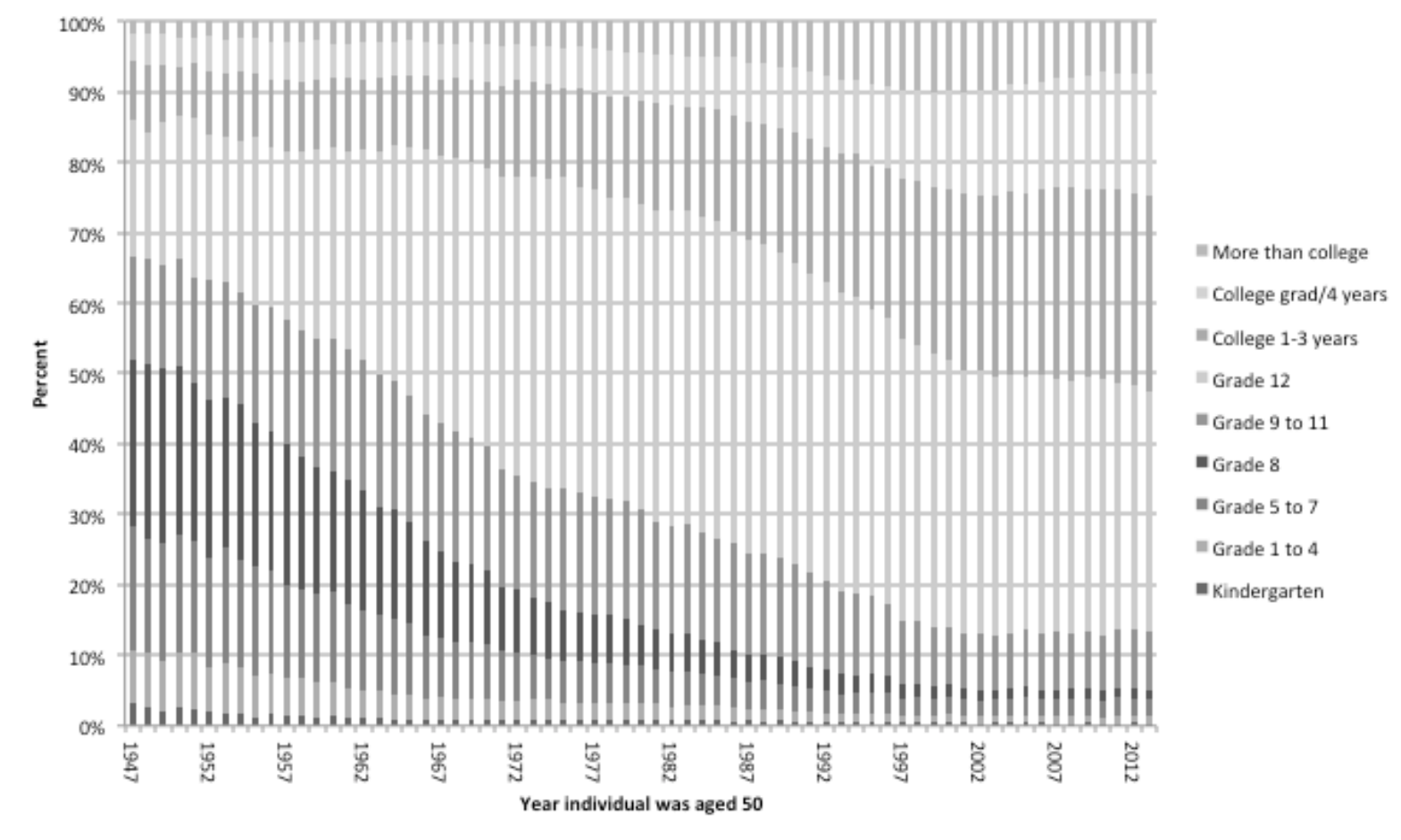




\section{Figure 15: Evolution of SAH by Education Quartile for Men}
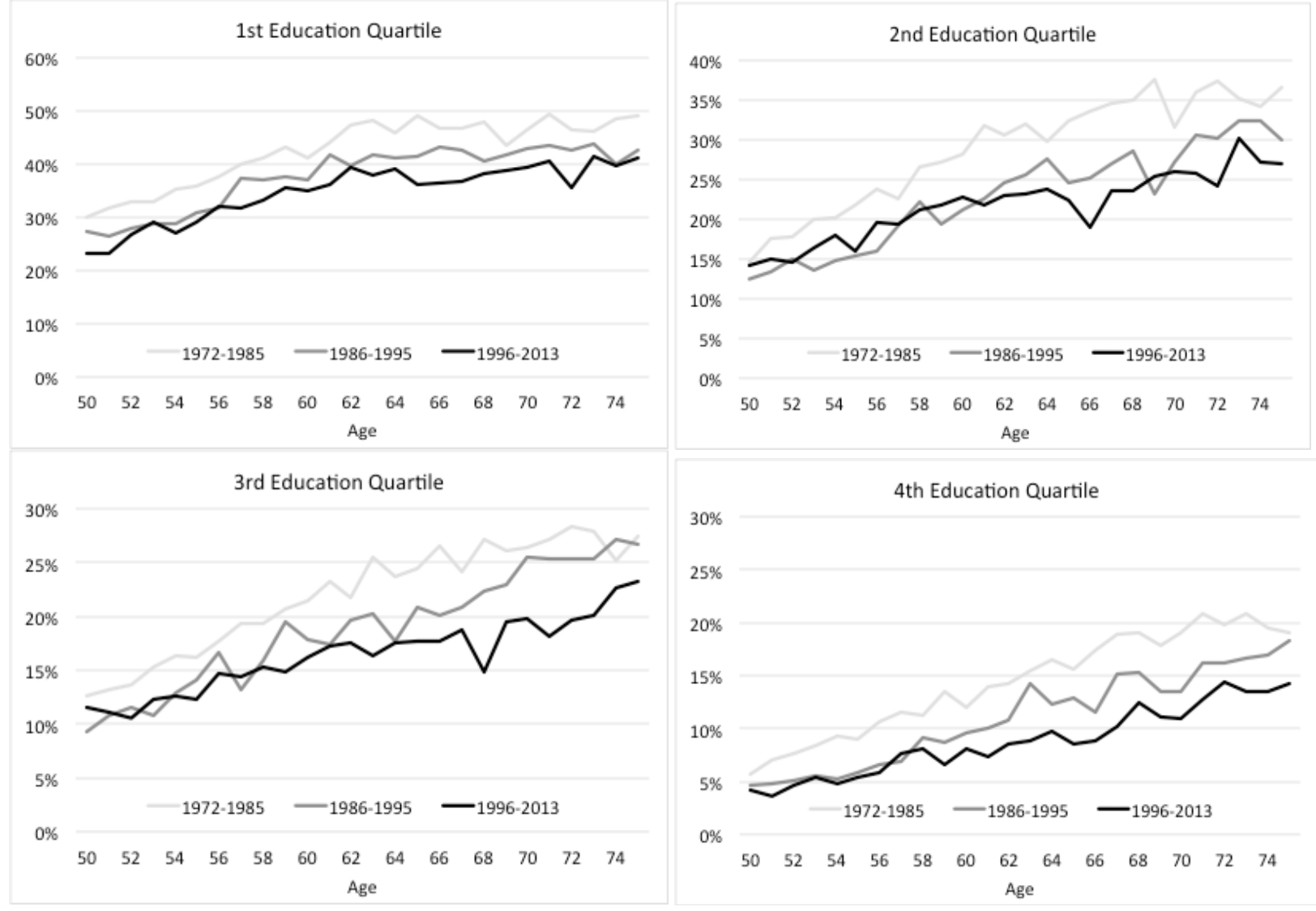


\section{Figure 16: Evolution of SAH by Education Quartile for Women}
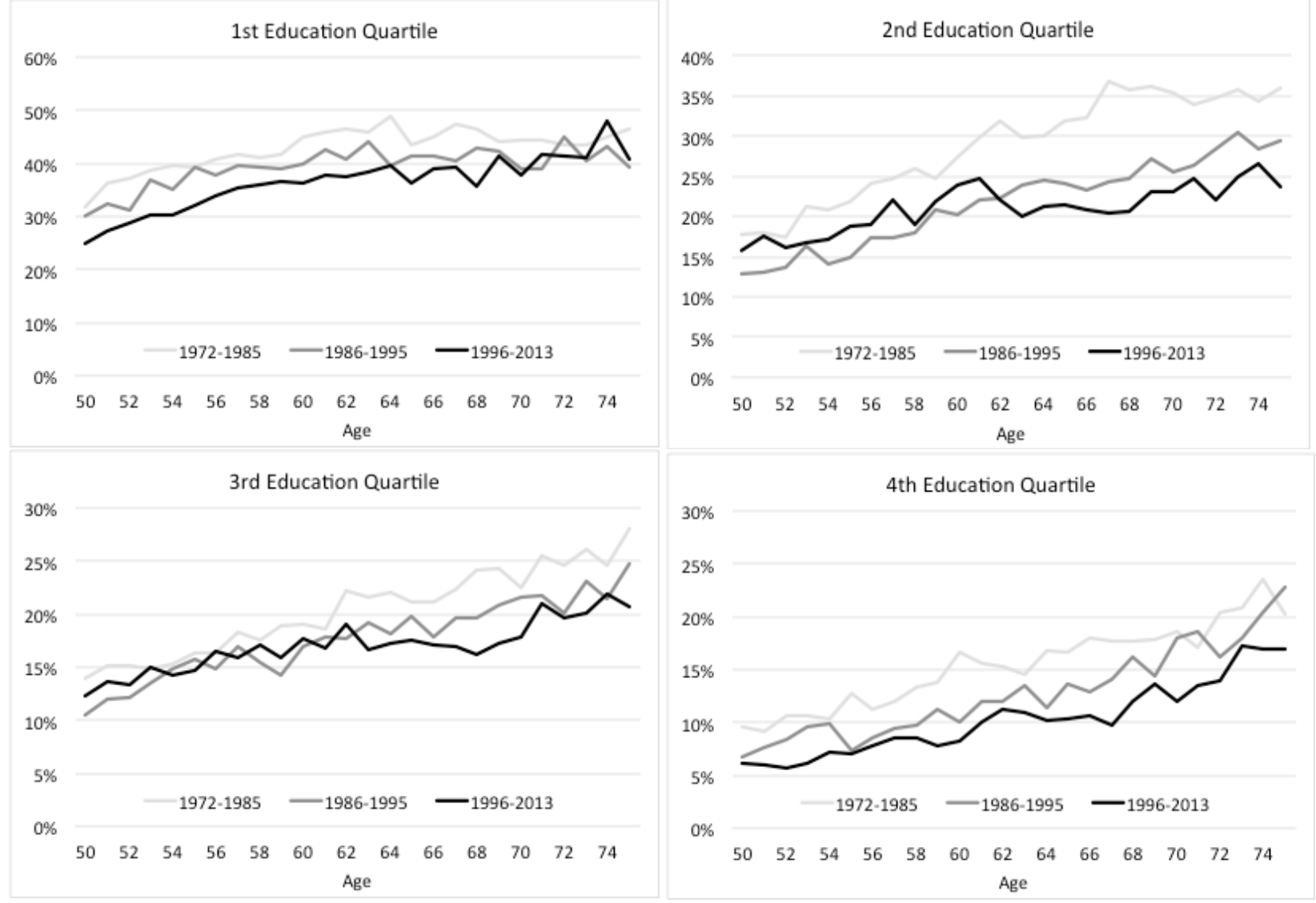


\begin{tabular}{ccccc}
\hline \multicolumn{5}{c}{ Table 1: Additional Employment Capacity in 2010 } \\
Ase & $\begin{array}{c}\text { Using 1977 Employment-Mortality Relationship } \\
\text { Death Rate } \\
\text { in 2010 }\end{array}$ & $\begin{array}{c}\text { Employment } \\
\text { Rate in 2010 }\end{array}$ & $\begin{array}{c}\text { Employment } \\
\text { Rate in 1977 } \\
\text { at Same }\end{array}$ & $\begin{array}{c}\text { Additional } \\
\text { Employment } \\
\text { Capacity }\end{array}$ \\
\hline 55 & & & Death Rate & \\
\hline 56 & $0.78 \%$ & $71.8 \%$ & $89.1 \%$ & $17.3 \%$ \\
57 & $0.84 \%$ & $75.0 \%$ & $88.1 \%$ & $13.1 \%$ \\
58 & $0.91 \%$ & $70.9 \%$ & $85.4 \%$ & $14.4 \%$ \\
59 & $0.98 \%$ & $68.8 \%$ & $84.1 \%$ & $15.3 \%$ \\
60 & $1.04 \%$ & $65.9 \%$ & $83.6 \%$ & $17.6 \%$ \\
61 & $1.11 \%$ & $62.3 \%$ & $83.9 \%$ & $21.5 \%$ \\
62 & $1.15 \%$ & $63.6 \%$ & $83.8 \%$ & $20.2 \%$ \\
63 & $1.26 \%$ & $54.7 \%$ & $83.7 \%$ & $28.9 \%$ \\
64 & $1.40 \%$ & $54.3 \%$ & $82.3 \%$ & $28.0 \%$ \\
65 & $1.40 \%$ & $46.0 \%$ & $82.2 \%$ & $36.2 \%$ \\
66 & $1.59 \%$ & $36.6 \%$ & $77.4 \%$ & $40.8 \%$ \\
67 & $1.71 \%$ & $34.1 \%$ & $76.2 \%$ & $42.1 \%$ \\
68 & $1.89 \%$ & $32.6 \%$ & $75.9 \%$ & $43.4 \%$ \\
69 & $2.00 \%$ & $31.7 \%$ & $76.5 \%$ & $44.8 \%$ \\
\hline Average: $65-69$ & $2.19 \%$ & $26.5 \%$ & $64.4 \%$ & $37.9 \%$ \\
\hline & & 7.9 & & 4.2 \\
\hline Average: $55-59$ & $0.9 \%$ & $70.5 \%$ & $86.0 \%$ & $27.0 \%$ \\
\hline
\end{tabular}




\begin{tabular}{|c|c|c|c|c|c|}
\hline \multicolumn{6}{|c|}{ Table 2a: Summary Statistics, Men } \\
\hline & \multicolumn{5}{|c|}{ Age Group } \\
\hline & 51-54 & $55-59$ & $60-64$ & 65-69 & 70-74 \\
\hline Employed & 0.7907 & 0.7455 & 0.5870 & 0.3895 & 0.2694 \\
\hline Health: Excellent & 0.1755 & 0.1647 & 0.1412 & 0.1236 & 0.1101 \\
\hline Health: Very Good & 0.3162 & 0.3117 & 0.3102 & 0.3019 & 0.2893 \\
\hline Health: Good & 0.2886 & 0.2964 & 0.3048 & 0.3240 & 0.3317 \\
\hline Health: Fair & 0.1569 & 0.1561 & 0.1746 & 0.1853 & 0.1966 \\
\hline Health: Poor & 0.0629 & 0.0711 & 0.0692 & 0.0652 & 0.0723 \\
\hline Physicial Limits: One & 0.2376 & 0.2709 & 0.2692 & 0.2761 & 0.2346 \\
\hline Phyisical Limits: Many & 0.3324 & 0.3753 & 0.4280 & 0.4685 & 0.4800 \\
\hline ADL: Any & 0.0955 & 0.0983 & 0.1063 & 0.1010 & 0.1224 \\
\hline IADL: Any & 0.0508 & 0.0460 & 0.0448 & 0.0431 & 0.0550 \\
\hline CESD Score (0-8) & 1.4267 & 1.3385 & 1.2165 & 1.0849 & 1.1031 \\
\hline Heart Disease & 0.1050 & 0.1449 & 0.1930 & 0.2542 & 0.3178 \\
\hline Stroke & 0.0370 & 0.0477 & 0.0654 & 0.0868 & 0.1079 \\
\hline Psychiatric Condition & 0.0279 & 0.0395 & 0.0533 & 0.0678 & 0.0893 \\
\hline Lung Disease & 0.1067 & 0.1044 & 0.1012 & 0.0883 & 0.0826 \\
\hline Cancer & 0.0300 & 0.0463 & 0.0772 & 0.1213 & 0.1741 \\
\hline High Blood Pressure & 0.3754 & 0.4235 & 0.4811 & 0.5302 & 0.5632 \\
\hline Arthritis & 0.2639 & 0.3419 & 0.4309 & 0.5097 & 0.5202 \\
\hline Diabetes & 0.1261 & 0.1520 & 0.1841 & 0.2086 & 0.2270 \\
\hline Weight: Under & 0.0026 & 0.0046 & 0.0054 & 0.0050 & 0.0053 \\
\hline Weight: Over & 0.4543 & 0.4591 & 0.4507 & 0.4671 & 0.4626 \\
\hline Weight: Obese & 0.3354 & 0.3184 & 0.3067 & 0.2902 & 0.2639 \\
\hline Smoker: Former & 0.3757 & 0.4339 & 0.4971 & 0.5519 & 0.6031 \\
\hline Smoker: Current & 0.2742 & 0.2433 & 0.2073 & 0.1635 & 0.1170 \\
\hline Education: HS Dropout & 0.1516 & 0.1644 & 0.1938 & 0.2193 & 0.2464 \\
\hline Education: HS Graduate & 0.3090 & 0.3137 & 0.3259 & 0.3417 & 0.3354 \\
\hline Education: Some College & 0.2706 & 0.2517 & 0.2220 & 0.1935 & 0.1825 \\
\hline Education: College Grad & 0.2688 & 0.2700 & 0.2580 & 0.2450 & 0.2354 \\
\hline Race: Hispanic & 0.1404 & 0.1166 & 0.0946 & 0.0851 & 0.0755 \\
\hline Race: Black & 0.1722 & 0.1562 & 0.1485 & 0.1267 & 0.1180 \\
\hline Race: Other & 0.0407 & 0.0281 & 0.0251 & 0.0200 & 0.0187 \\
\hline Married & 0.7872 & 0.7960 & 0.8128 & 0.8338 & 0.8108 \\
\hline Occupation: Blue Collar & 0.2676 & 0.3520 & 0.4089 & 0.4348 & 0.3943 \\
\hline Occupation: Low Skill & 0.0477 & 0.0560 & 0.0593 & 0.0601 & 0.0551 \\
\hline Health Insurance: Own & 0.5521 & 0.5690 & 0.5480 & 0.3583 & 0.2712 \\
\hline Health Insurance: Spouse & 0.1368 & 0.1365 & 0.1378 & 0.0975 & 0.0509 \\
\hline Pension Coverage & 0.5050 & 0.5220 & 0.5162 & 0.4925 & 0.4422 \\
\hline \# Obs & 5,725 & 12,405 & 12,300 & 10,727 & 10,372 \\
\hline
\end{tabular}


Table 2b: Summary Statistics, Women

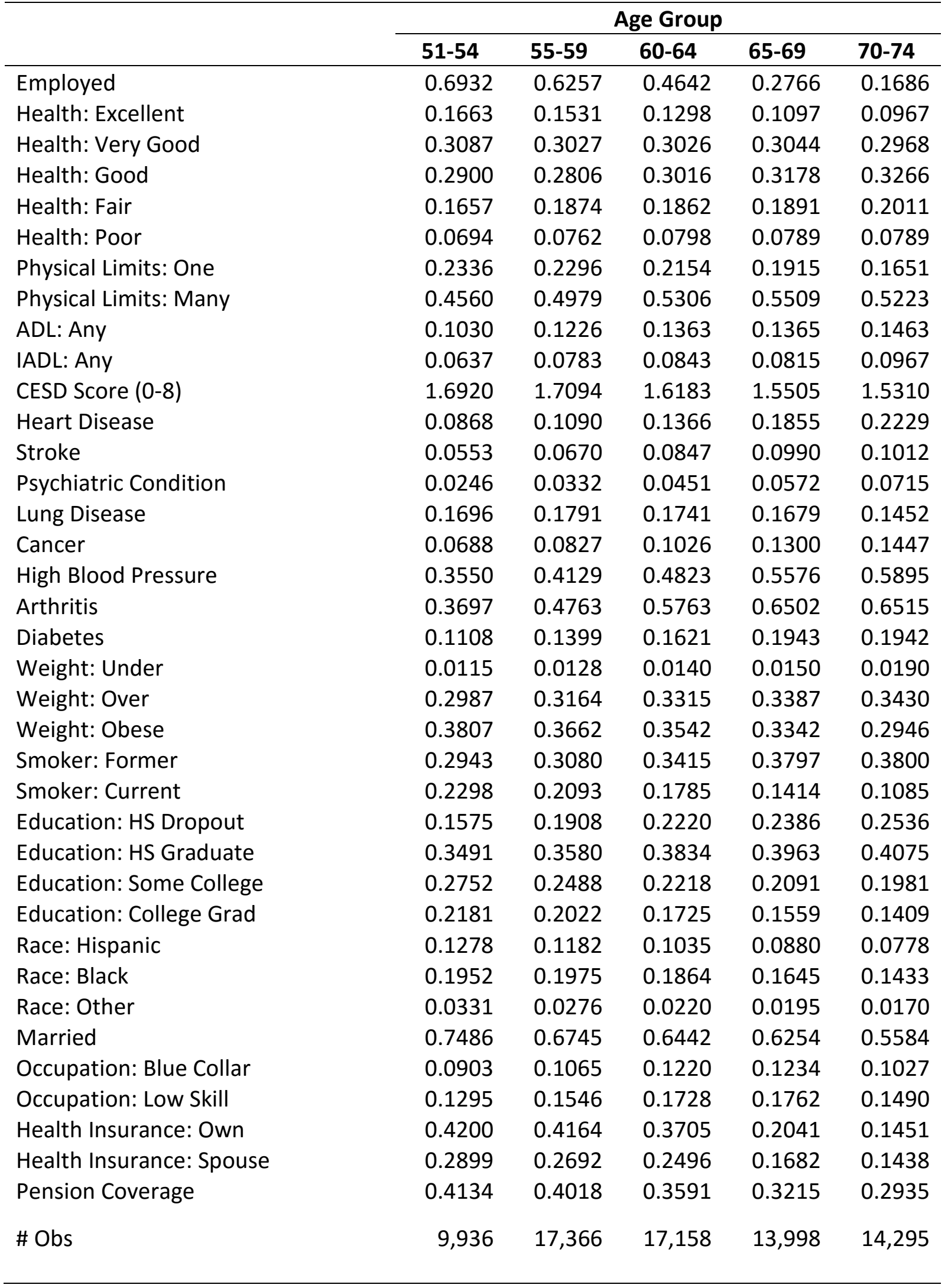


Table 3a: Employment Regressions, All Health Variables

\begin{tabular}{|c|c|c|c|c|c|c|}
\hline \multirow[b]{2}{*}{ Variable } & \multicolumn{3}{|c|}{ Men 51-54 } & \multicolumn{3}{|c|}{ Women 51-54 } \\
\hline & Coefficient & Std Error & & Coefficient & Std Error & \\
\hline Health: Very Good & -0.0137 & 0.0129 & & -0.0009 & 0.0114 & \\
\hline Health: Good & -0.0233 & 0.0140 & $*$ & -0.0033 & 0.0124 & \\
\hline Health: Fair & -0.0904 & 0.0175 & $* *$ & -0.0707 & 0.0153 & $* *$ \\
\hline Health: Poor & -0.2046 & 0.0247 & $* *$ & -0.1835 & 0.0211 & $* *$ \\
\hline Physical Limits: One & 0.0054 & 0.0111 & & 0.0141 & 0.0103 & \\
\hline Physical Limits: Many & -0.0118 & 0.0110 & & 0.0063 & 0.0091 & \\
\hline ADL: Any & -0.2004 & 0.0180 & $* *$ & -0.1282 & 0.0152 & $* *$ \\
\hline IADL: Any & -0.1448 & 0.0228 & $* *$ & -0.1259 & 0.0180 & $* *$ \\
\hline CESD Score (0-8) & -0.0047 & 0.0027 & $*$ & -0.0090 & 0.0020 & $* *$ \\
\hline Heart Disease & -0.0319 & 0.0147 & $* *$ & -0.0358 & 0.0138 & $* *$ \\
\hline Stroke & -0.0327 & 0.0234 & & -0.0578 & 0.0171 & $* *$ \\
\hline Psychiatric Condition & -0.1060 & 0.0268 & $* *$ & -0.0362 & 0.0245 & \\
\hline Lung Disease & -0.0993 & 0.0153 & $* *$ & -0.0749 & 0.0108 & $* *$ \\
\hline Cancer & -0.0423 & 0.250 & $*$ & -0.0250 & 0.0146 & $*$ \\
\hline High Blood Pressure & -0.0189 & 0.0096 & $* *$ & -0.0041 & 0.0086 & \\
\hline Arthritis & -0.0094 & 0.0105 & & -0.0021 & 0.0084 & \\
\hline Diabetes & -0.0539 & 0.0137 & $* *$ & -0.0237 & 0.0126 & $*$ \\
\hline Weight: Under & -0.0726 & 0.0835 & & -0.0655 & 0.0350 & $*$ \\
\hline Weight: Over & -0.0011 & 0.0115 & & -0.0015 & 0.0097 & \\
\hline Weight: Obese & 0.0068 & 0.0126 & & -0.0135 & 0.0100 & \\
\hline Smoker: Former & -0.0161 & 0.0102 & & 0.0195 & 0.0087 & $* *$ \\
\hline Smoker: Current & -0.0232 & 0.0118 & $* *$ & -0.0045 & 0.0098 & \\
\hline Education: HS Dropout & -0.0038 & 0.0142 & & -0.0462 & 0.0122 & $* *$ \\
\hline Education: Some College & 0.0045 & 0.0113 & & 0.0237 & 0.0095 & $* *$ \\
\hline Education: College Grad & 0.0028 & 0.0126 & & 0.0178 & 0.0108 & $*$ \\
\hline Race: Hispanic & 0.0365 & 0.0141 & $* *$ & 0.0288 & 0.0128 & $* *$ \\
\hline Race: Black & -0.0356 & 0.0123 & $* *$ & -0.0431 & 0.0105 & $* *$ \\
\hline Race: Other & 0.0016 & 0.0219 & & -0.0027 & 0.0209 & \\
\hline Married & 0.0748 & 0.0112 & $* *$ & -0.0156 & 0.0094 & $*$ \\
\hline Occupation: Blue Collar & -0.0155 & 0.0119 & & 0.0736 & 0.0137 & $* *$ \\
\hline Occupation: Low Skill & -0.0301 & 0.0212 & & 0.1294 & 0.0118 & $* *$ \\
\hline Health Insurance: Own & 0.1651 & 0.0122 & $* *$ & 0.1979 & 0.0106 & $* *$ \\
\hline Health Insurance: Spouse & 0.0832 & 0.0142 & $* *$ & 0.0236 & 0.0102 & $* *$ \\
\hline Pension Coverage & 0.1602 & 0.0111 & $* *$ & 0.2886 & 0.0095 & $* *$ \\
\hline \# Obs & 5,725 & & & 9,936 & & \\
\hline
\end{tabular}


Table 3b: Employment Regressions, PVW Health Index

\begin{tabular}{|c|c|c|c|c|c|c|}
\hline \multirow[b]{2}{*}{ Variable } & \multicolumn{3}{|c|}{ Men 51-54 } & \multicolumn{3}{|c|}{ Women 51-54 } \\
\hline & Coefficient & Std Error & & Coefficient & Std Error & \\
\hline PVW index & 0.0048 & 0.0002 & $* *$ & 0.0034 & 0.0001 & $* *$ \\
\hline Education: HS Dropout & -0.0123 & 0.0145 & & -0.0700 & 0.0124 & $* *$ \\
\hline Education: Some College & 0.0078 & 0.0116 & & 0.0220 & 0.0097 & $* *$ \\
\hline Education: College Grad & -0.0071 & 0.0126 & & 0.0131 & 0.0108 & \\
\hline Race: Hispanic & 0.0236 & 0.0141 & $*$ & 0.0323 & 0.0127 & $* *$ \\
\hline Race: Black & -0.0478 & 0.0124 & $* *$ & -0.0350 & 0.0103 & $* *$ \\
\hline Race: Other & -0.0137 & 0.0223 & & -0.0138 & 0.0213 & \\
\hline Married & 0.0898 & 0.0112 & $* *$ & -0.0026 & 0.0095 & \\
\hline Occupation: Blue Collar & -0.0100 & 0.0122 & & 0.0749 & 0.0140 & $* *$ \\
\hline Occupation: Low Skill & -0.0344 & 0.0218 & & 0.1376 & 0.0121 & $* *$ \\
\hline Health Insurance: Own & 0.1869 & 0.0124 & $* *$ & 0.2294 & 0.0108 & $* *$ \\
\hline Health Insurance: Spouse & 0.1046 & 0.0144 & $* *$ & 0.0487 & 0.0104 & $* *$ \\
\hline Pension Coverage & 0.1714 & 0.0113 & $* *$ & 0.3001 & 0.0097 & $* *$ \\
\hline \# Obs & 5,662 & & & 9,842 & & \\
\hline
\end{tabular}

Note: Sample size is slightly smaller than in models on Table 3a due to missing observations for PVW index for some observations. 
Table 4: Simulations of Work Capacity

\begin{tabular}{|c|c|c|c|c|c|c|c|c|}
\hline \multirow[b]{2}{*}{$\begin{array}{l}\text { Age } \\
\text { Group }\end{array}$} & \multicolumn{4}{|c|}{ Use All Health Variables } & \multicolumn{4}{|c|}{ Use PVW Health Index } \\
\hline & \# Obs & $\begin{array}{c}\text { Actual } \\
\% \text { Working }\end{array}$ & $\begin{array}{l}\text { Predicted } \\
\% \text { Working }\end{array}$ & $\begin{array}{l}\text { Estimated } \\
\text { Work } \\
\text { Capacity }\end{array}$ & \# Obs & $\begin{array}{c}\text { Actual } \\
\% \text { Working }\end{array}$ & $\begin{array}{l}\text { Predicted } \\
\% \text { Working }\end{array}$ & $\begin{array}{c}\text { Estimated } \\
\text { Work } \\
\text { Capacity }\end{array}$ \\
\hline & \multicolumn{8}{|c|}{ MEN } \\
\hline $55-59$ & 12,405 & $74.6 \%$ & $78.5 \%$ & $3.9 \%$ & 12,331 & $74.6 \%$ & $78.2 \%$ & $3.6 \%$ \\
\hline $60-64$ & 12,300 & $58.7 \%$ & $76.8 \%$ & $18.1 \%$ & 12,229 & $58.7 \%$ & $75.6 \%$ & $16.9 \%$ \\
\hline $65-69$ & 10,727 & $38.9 \%$ & $73.2 \%$ & $34.2 \%$ & 10,626 & $39.0 \%$ & $70.4 \%$ & $31.4 \%$ \\
\hline \multirow[t]{2}{*}{$70-74$} & 10,372 & $26.9 \%$ & $68.5 \%$ & $41.6 \%$ & 9,581 & $27.2 \%$ & $66.2 \%$ & $39.0 \%$ \\
\hline & \multicolumn{8}{|c|}{ WOMEN } \\
\hline $55-59$ & 17,366 & $62.6 \%$ & $67.6 \%$ & $5.0 \%$ & 17,255 & $62.6 \%$ & $67.1 \%$ & $4.5 \%$ \\
\hline $60-64$ & 17,158 & $46.4 \%$ & $64.9 \%$ & $18.5 \%$ & 16,969 & $46.5 \%$ & $63.2 \%$ & $16.7 \%$ \\
\hline $65-69$ & 13,998 & $27.7 \%$ & $60.4 \%$ & $32.8 \%$ & 13,585 & $27.7 \%$ & $57.0 \%$ & $29.3 \%$ \\
\hline $70-74$ & 13,681 & $16.9 \%$ & $57.6 \%$ & $40.7 \%$ & 12,576 & $16.8 \%$ & $54.2 \%$ & $37.4 \%$ \\
\hline
\end{tabular}




\begin{tabular}{|c|c|c|c|c|c|c|c|c|}
\hline \multicolumn{9}{|c|}{ Table 5a: Work Capacity by Education (Regression by Education Group) } \\
\hline \multirow[t]{2}{*}{ Education } & \multicolumn{4}{|c|}{ Men, All Health Variables Model } & \multicolumn{4}{|c|}{ Men, PVW Model } \\
\hline & Obs & $\begin{array}{c}\text { Actual } \\
\% \text { Working }\end{array}$ & $\begin{array}{l}\text { Predicted } \\
\% \text { Working }\end{array}$ & $\begin{array}{l}\text { Estimated } \\
\text { Work } \\
\text { Capacity }\end{array}$ & Obs & $\begin{array}{c}\text { Actual } \\
\% \text { Working }\end{array}$ & $\begin{array}{l}\text { Predicted } \\
\% \text { Working }\end{array}$ & $\begin{array}{c}\text { Estimated } \\
\text { Work } \\
\text { Capacity }\end{array}$ \\
\hline & \multicolumn{8}{|c|}{ Age 55-59 } \\
\hline$<$ High School & 2,039 & $60.4 \%$ & $63.8 \%$ & $3.4 \%$ & 2,019 & $60.6 \%$ & $63.4 \%$ & $2.7 \%$ \\
\hline High School & 3,891 & $71.9 \%$ & $78.2 \%$ & $6.3 \%$ & 3,864 & $71.9 \%$ & $77.5 \%$ & $5.6 \%$ \\
\hline Some College & 3,122 & $75.9 \%$ & $77.8 \%$ & $1.8 \%$ & 3,104 & $75.9 \%$ & $78.2 \%$ & $2.3 \%$ \\
\hline \multirow[t]{2}{*}{ College Grad } & 3,349 & $84.9 \%$ & $89.2 \%$ & $4.3 \%$ & 3,344 & $84.9 \%$ & $88.5 \%$ & $3.6 \%$ \\
\hline & \multicolumn{8}{|c|}{ Age $60-64$} \\
\hline$<$ High School & 2,384 & $46.6 \%$ & $64.3 \%$ & $17.6 \%$ & 2,367 & $46.8 \%$ & $62.2 \%$ & $15.4 \%$ \\
\hline High School & 4,009 & $54.8 \%$ & $77.4 \%$ & $22.6 \%$ & 3,980 & $54.6 \%$ & $75.2 \%$ & $20.6 \%$ \\
\hline Some College & 2,731 & $61.0 \%$ & $76.1 \%$ & $15.2 \%$ & 2,711 & $61.0 \%$ & $76.3 \%$ & $15.2 \%$ \\
\hline \multirow[t]{2}{*}{ College Grad } & 3,174 & $70.7 \%$ & $87.7 \%$ & $17.0 \%$ & 3,169 & $70.7 \%$ & $86.8 \%$ & $16.0 \%$ \\
\hline & \multicolumn{8}{|c|}{ Age $65-69$} \\
\hline$<$ High School & 2,352 & $30.6 \%$ & $62.7 \%$ & $32.1 \%$ & 2,318 & $30.7 \%$ & $58.5 \%$ & $27.8 \%$ \\
\hline High School & 3,665 & $35.0 \%$ & $73.5 \%$ & $38.5 \%$ & 3,631 & $34.8 \%$ & $69.8 \%$ & $35.0 \%$ \\
\hline Some College & 2,076 & $38.6 \%$ & $73.1 \%$ & $34.5 \%$ & 2,059 & $38.9 \%$ & $72.3 \%$ & $33.4 \%$ \\
\hline \multirow[t]{2}{*}{ College Grad } & 2,628 & $52.1 \%$ & $84.0 \%$ & $31.9 \%$ & 2,612 & $52.1 \%$ & $82.3 \%$ & $30.2 \%$ \\
\hline & \multicolumn{8}{|c|}{ Age $70-74$} \\
\hline$<$ High School & 2,556 & $19.9 \%$ & $58.3 \%$ & $38.4 \%$ & 2,302 & $20.1 \%$ & $55.2 \%$ & $35.1 \%$ \\
\hline High School & 3,479 & $24.3 \%$ & $69.9 \%$ & $45.7 \%$ & 3,221 & $24.1 \%$ & $66.4 \%$ & $42.3 \%$ \\
\hline Some College & 1,893 & $26.9 \%$ & $68.7 \%$ & $41.8 \%$ & 1,756 & $27.7 \%$ & $67.8 \%$ & $40.1 \%$ \\
\hline College Grad & 2,442 & $38.1 \%$ & $80.2 \%$ & $42.1 \%$ & 2,300 & $38.2 \%$ & $79.0 \%$ & $40.8 \%$ \\
\hline
\end{tabular}

Note: Actual \% working in All Health and PVW models may differ due to differences in sample size 


\begin{tabular}{|c|c|c|c|c|c|c|c|c|}
\hline \multicolumn{9}{|c|}{ Table 5b: Work Capacity by Education (Regression by Education Group) } \\
\hline \multirow[t]{2}{*}{ Education } & \multicolumn{4}{|c|}{ Women, All Health Variables Model } & \multicolumn{4}{|c|}{ Women, PVW Model } \\
\hline & Obs & $\begin{array}{c}\text { Actual } \\
\% \text { Working }\end{array}$ & $\begin{array}{l}\text { Predicted } \\
\% \text { Working }\end{array}$ & $\begin{array}{l}\text { Estimated } \\
\text { Work } \\
\text { Capacity }\end{array}$ & Obs & $\begin{array}{c}\text { Actual } \\
\% \text { Working }\end{array}$ & $\begin{array}{l}\text { Predicted } \\
\% \text { Working }\end{array}$ & $\begin{array}{c}\text { Estimated } \\
\text { Work } \\
\text { Capacity }\end{array}$ \\
\hline & \multicolumn{8}{|c|}{ Age 55-59 } \\
\hline$<$ High School & 3,314 & $41.2 \%$ & $46.6 \%$ & $5.4 \%$ & 3,296 & $41.2 \%$ & $46.1 \%$ & $4.9 \%$ \\
\hline High School & 6,217 & $62.6 \%$ & $66.9 \%$ & $4.3 \%$ & 6,178 & $62.5 \%$ & $66.4 \%$ & $3.9 \%$ \\
\hline Some College & 4,320 & $68.1 \%$ & $73.0 \%$ & $4.9 \%$ & 4,285 & $68.3 \%$ & $72.5 \%$ & $4.1 \%$ \\
\hline \multirow[t]{2}{*}{ College Grad } & 3,512 & $75.9 \%$ & $81.4 \%$ & $5.5 \%$ & 3,493 & $75.9 \%$ & $81.3 \%$ & $5.4 \%$ \\
\hline & \multicolumn{8}{|c|}{ Age $60-64$} \\
\hline$<$ High School & 3,809 & $30.8 \%$ & $45.6 \%$ & $14.8 \%$ & 3,768 & $30.8 \%$ & $44.3 \%$ & $13.4 \%$ \\
\hline High School & 6,579 & $45.9 \%$ & $64.3 \%$ & $18.4 \%$ & 6,515 & $45.9 \%$ & $62.6 \%$ & $16.7 \%$ \\
\hline Some College & 3,805 & $53.2 \%$ & $72.1 \%$ & $19.0 \%$ & 3,749 & $53.4 \%$ & $69.9 \%$ & $16.5 \%$ \\
\hline \multirow[t]{2}{*}{ College Grad } & 2,960 & $58.9 \%$ & $80.5 \%$ & $21.6 \%$ & 2,932 & $58.9 \%$ & $79.6 \%$ & $20.7 \%$ \\
\hline & \multicolumn{8}{|c|}{ Age $65-69$} \\
\hline$<$ High School & 3,340 & $18.2 \%$ & $44.1 \%$ & $25.9 \%$ & 3,232 & $18.3 \%$ & $41.9 \%$ & $23.6 \%$ \\
\hline High School & 5,548 & $27.3 \%$ & $59.7 \%$ & $32.4 \%$ & 5,392 & $27.3 \%$ & $56.5 \%$ & $29.3 \%$ \\
\hline Some College & 2,927 & $32.0 \%$ & $69.0 \%$ & $36.9 \%$ & 2,837 & $32.0 \%$ & $63.7 \%$ & $31.7 \%$ \\
\hline \multirow[t]{2}{*}{ College Grad } & 2,182 & $37.3 \%$ & $74.6 \%$ & $37.3 \%$ & 2,123 & $37.6 \%$ & $73.4 \%$ & $35.8 \%$ \\
\hline & \multicolumn{8}{|c|}{ Age $70-74$} \\
\hline$<$ High School & 3,469 & $12.3 \%$ & $42.8 \%$ & $30.5 \%$ & 3,151 & $12.3 \%$ & $41.4 \%$ & $29.1 \%$ \\
\hline High School & 5,575 & $15.9 \%$ & $57.0 \%$ & $41.1 \%$ & 5,131 & $15.8 \%$ & $53.8 \%$ & $38.0 \%$ \\
\hline Some College & 2,710 & $20.7 \%$ & $66.5 \%$ & $45.8 \%$ & 2,494 & $20.4 \%$ & $60.8 \%$ & $40.4 \%$ \\
\hline College Grad & 1,927 & $22.3 \%$ & $70.4 \%$ & $48.0 \%$ & 1,800 & $22.8 \%$ & $70.4 \%$ & $47.7 \%$ \\
\hline
\end{tabular}

Note: Actual \% working in All Health and PVW models may differ due to differences in sample size 


\begin{tabular}{|c|c|c|c|c|c|c|c|c|}
\hline \multicolumn{9}{|c|}{ Table 6a: Work Capacity by Education (Single Regression) } \\
\hline \multirow[t]{2}{*}{ Education } & \multicolumn{4}{|c|}{ Men, All Health Variables Model } & \multicolumn{4}{|c|}{ Men, PVW Model } \\
\hline & Obs & $\begin{array}{c}\text { Actual } \\
\% \text { Working }\end{array}$ & $\begin{array}{l}\text { Predicted } \\
\% \text { Working }\end{array}$ & $\begin{array}{l}\text { Estimated } \\
\text { Work } \\
\text { Capacity }\end{array}$ & Obs & $\begin{array}{c}\text { Actual } \\
\% \text { Working }\end{array}$ & $\begin{array}{l}\text { Predicted } \\
\% \text { Working }\end{array}$ & $\begin{array}{c}\text { Estimated } \\
\text { Work } \\
\text { Capacity }\end{array}$ \\
\hline & \multicolumn{8}{|c|}{ Age $55-59$} \\
\hline$<$ High School & 2,039 & $60.4 \%$ & $63.6 \%$ & $3.2 \%$ & 2,019 & $60.6 \%$ & $63.6 \%$ & $3.0 \%$ \\
\hline High School & 3,891 & $71.9 \%$ & $76.8 \%$ & $4.9 \%$ & 3,864 & $71.9 \%$ & $76.3 \%$ & $4.4 \%$ \\
\hline Some College & 3,122 & $75.9 \%$ & $79.1 \%$ & $3.2 \%$ & 3,104 & $75.9 \%$ & $79.0 \%$ & $3.1 \%$ \\
\hline \multirow[t]{2}{*}{ College Grad } & 3,349 & $84.9 \%$ & $88.9 \%$ & $4.0 \%$ & 3,344 & $84.9 \%$ & $88.4 \%$ & $3.5 \%$ \\
\hline & \multicolumn{8}{|c|}{ Age $60-64$} \\
\hline$<$ High School & 2,384 & $46.6 \%$ & $63.6 \%$ & $17.0 \%$ & 2,367 & $46.8 \%$ & $62.7 \%$ & $16.0 \%$ \\
\hline High School & 4,009 & $54.8 \%$ & $76.6 \%$ & $21.8 \%$ & 3,980 & $54.6 \%$ & $74.9 \%$ & $20.2 \%$ \\
\hline Some College & 2,731 & $61.0 \%$ & $77.4 \%$ & $16.4 \%$ & 2,711 & $61.0 \%$ & $76.7 \%$ & $15.7 \%$ \\
\hline \multirow[t]{2}{*}{ College Grad } & 3,174 & $70.7 \%$ & $86.5 \%$ & $15.8 \%$ & 3,169 & $70.7 \%$ & $85.2 \%$ & $14.4 \%$ \\
\hline & \multicolumn{8}{|c|}{ Age $65-69$} \\
\hline$<$ High School & 2,352 & $30.6 \%$ & $63.0 \%$ & $32.4 \%$ & 2,318 & $30.7 \%$ & $60.1 \%$ & $29.4 \%$ \\
\hline High School & 3,665 & $35.0 \%$ & $73.4 \%$ & $38.3 \%$ & 3,631 & $34.8 \%$ & $70.2 \%$ & $35.4 \%$ \\
\hline Some College & 2,076 & $38.6 \%$ & $73.5 \%$ & $34.9 \%$ & 2,059 & $38.9 \%$ & $71.5 \%$ & $32.7 \%$ \\
\hline \multirow[t]{2}{*}{ College Grad } & 2,628 & $52.1 \%$ & $81.7 \%$ & $29.5 \%$ & 2,612 & $52.1 \%$ & $79.0 \%$ & $26.9 \%$ \\
\hline & \multicolumn{8}{|c|}{ Age $70-74$} \\
\hline$<$ High School & 2,556 & $19.9 \%$ & $59.2 \%$ & $39.2 \%$ & 2,302 & $20.1 \%$ & $57.4 \%$ & $37.2 \%$ \\
\hline High School & 3,479 & $24.3 \%$ & $69.0 \%$ & $44.7 \%$ & 3,221 & $24.1 \%$ & $66.4 \%$ & $42.3 \%$ \\
\hline Some College & 1,893 & $26.9 \%$ & $69.1 \%$ & $42.2 \%$ & 1,756 & $27.7 \%$ & $67.0 \%$ & $39.3 \%$ \\
\hline College Grad & 2,442 & $38.1 \%$ & $77.3 \%$ & $39.2 \%$ & 2,300 & $38.2 \%$ & $74.2 \%$ & $36.0 \%$ \\
\hline
\end{tabular}

Note: Actual \% working in All Health and PVW models may differ due to differences in sample size 


\begin{tabular}{|c|c|c|c|c|c|c|c|c|}
\hline \multicolumn{9}{|c|}{ Table 6b: Work Capacity by Education (Single Regression) } \\
\hline \multirow[t]{2}{*}{ Education } & \multicolumn{4}{|c|}{ Women, All Health Variables Model } & \multicolumn{4}{|c|}{ Women, PVW Model } \\
\hline & Obs & $\begin{array}{c}\text { Actual } \\
\% \text { Working }\end{array}$ & $\begin{array}{l}\text { Predicted } \\
\% \text { Working }\end{array}$ & $\begin{array}{c}\text { Estimated } \\
\text { Work } \\
\text { Capacity }\end{array}$ & Obs & $\begin{array}{c}\text { Actual } \\
\% \text { Working }\end{array}$ & $\begin{array}{l}\text { Predicted } \\
\% \text { Working }\end{array}$ & $\begin{array}{c}\text { Estimated } \\
\text { Work } \\
\text { Capacity }\end{array}$ \\
\hline & \multicolumn{8}{|c|}{ Age 55-59 } \\
\hline$<$ High School & 3,314 & $41.2 \%$ & $47.0 \%$ & $5.8 \%$ & 3,296 & $41.2 \%$ & $46.8 \%$ & $5.6 \%$ \\
\hline High School & 6,217 & $62.6 \%$ & $67.4 \%$ & $4.8 \%$ & 6,178 & $62.5 \%$ & $66.9 \%$ & $4.3 \%$ \\
\hline Some College & 4,320 & $68.1 \%$ & $72.3 \%$ & $4.2 \%$ & 4,285 & $68.3 \%$ & $71.9 \%$ & $3.6 \%$ \\
\hline \multirow[t]{2}{*}{ College Grad } & 3,512 & $75.9 \%$ & $81.4 \%$ & $5.5 \%$ & 3,493 & $75.9 \%$ & $80.7 \%$ & $4.8 \%$ \\
\hline & \multicolumn{8}{|c|}{ Age $60-64$} \\
\hline$<$ High School & 3,809 & $30.8 \%$ & $46.3 \%$ & $15.5 \%$ & 3,768 & $30.8 \%$ & $45.5 \%$ & $14.7 \%$ \\
\hline High School & 6,579 & $45.9 \%$ & $65.2 \%$ & $19.3 \%$ & 6,515 & $45.9 \%$ & $63.4 \%$ & $17.5 \%$ \\
\hline Some College & 3,805 & $53.2 \%$ & $70.8 \%$ & $17.6 \%$ & 3,749 & $53.4 \%$ & $69.0 \%$ & $15.6 \%$ \\
\hline \multirow[t]{2}{*}{ College Grad } & 2,960 & $58.9 \%$ & $80.5 \%$ & $21.6 \%$ & 2,932 & $58.9 \%$ & $78.1 \%$ & $19.2 \%$ \\
\hline & \multicolumn{8}{|c|}{ Age $65-69$} \\
\hline$<$ High School & 3,340 & $18.2 \%$ & $45.7 \%$ & $27.4 \%$ & 3,232 & $18.3 \%$ & $43.4 \%$ & $25.1 \%$ \\
\hline High School & 5,548 & $27.3 \%$ & $61.4 \%$ & $34.1 \%$ & 5,392 & $27.3 \%$ & $57.8 \%$ & $30.6 \%$ \\
\hline Some College & 2,927 & $32.0 \%$ & $66.0 \%$ & $34.0 \%$ & 2,837 & $32.0 \%$ & $62.0 \%$ & $30.0 \%$ \\
\hline \multirow[t]{2}{*}{ College Grad } & 2,182 & $37.3 \%$ & $73.2 \%$ & $35.9 \%$ & 2,123 & $37.6 \%$ & $69.2 \%$ & $31.6 \%$ \\
\hline & \multicolumn{8}{|c|}{ Age $70-74$} \\
\hline$<$ High School & 3,469 & $12.3 \%$ & $44.6 \%$ & $32.3 \%$ & 3,151 & $12.3 \%$ & $42.5 \%$ & $30.2 \%$ \\
\hline High School & 5,575 & $15.9 \%$ & $58.8 \%$ & $42.9 \%$ & 5,131 & $15.8 \%$ & $55.3 \%$ & $39.5 \%$ \\
\hline Some College & 2,710 & $20.7 \%$ & $63.5 \%$ & $42.8 \%$ & 2,494 & $20.4 \%$ & $59.0 \%$ & $38.6 \%$ \\
\hline College Grad & 1,927 & $22.3 \%$ & $69.2 \%$ & $46.9 \%$ & 1,800 & $22.8 \%$ & $65.2 \%$ & $42.4 \%$ \\
\hline
\end{tabular}

Note: Actual \% working in All Health and PVW models may differ due to differences in sample size 


\begin{tabular}{|c|c|c|c|c|}
\hline & \multicolumn{2}{|c|}{ Men } & \multicolumn{2}{|c|}{ Women } \\
\hline & $\begin{array}{l}\text { All Health } \\
\text { Variable } \\
\text { Model }\end{array}$ & $\begin{array}{l}\text { PVW Index } \\
\text { Model }\end{array}$ & $\begin{array}{c}\text { All Health } \\
\text { Variable } \\
\text { Model }\end{array}$ & $\begin{array}{l}\text { PVW Index } \\
\text { Model }\end{array}$ \\
\hline \multirow[t]{2}{*}{ All } & 2.8 & 2.6 & 2.8 & 2.5 \\
\hline & \multicolumn{4}{|c|}{ By Education (Separate Regressions) } \\
\hline$<$ High School & 2.7 & 2.3 & 2.3 & 2.1 \\
\hline High School & 3.4 & 3.1 & 2.8 & 2.5 \\
\hline Some College & 2.6 & 2.5 & 3.0 & 2.6 \\
\hline \multirow[t]{2}{*}{ College Grad } & 2.7 & 2.5 & 3.2 & 3.1 \\
\hline & \multicolumn{4}{|c|}{ By Education (Single Regression) } \\
\hline$<$ High School & 2.6 & 2.4 & 2.4 & 2.3 \\
\hline High School & 3.3 & 3.0 & 2.9 & 2.6 \\
\hline Some College & 2.7 & 2.6 & 2.8 & 2.5 \\
\hline College Grad & 2.5 & 2.2 & 3.1 & 2.8 \\
\hline
\end{tabular}

Note: Calculated using estimated work capacity by age (at age 55-59, 60-64, 65-69) from Tables 4-6.

Table 8: Average Improvement in SAH at Ages 50-75 by Education Quartile

\begin{tabular}{lcccc}
\hline & 1st & 2nd & 3rd & 4th \\
\hline Men & $19 \%$ & $23 \%$ & $24 \%$ & $39 \%$ \\
Women & $15 \%$ & $25 \%$ & $15 \%$ & $34 \%$ \\
\hline
\end{tabular}

